Discussion

Papers

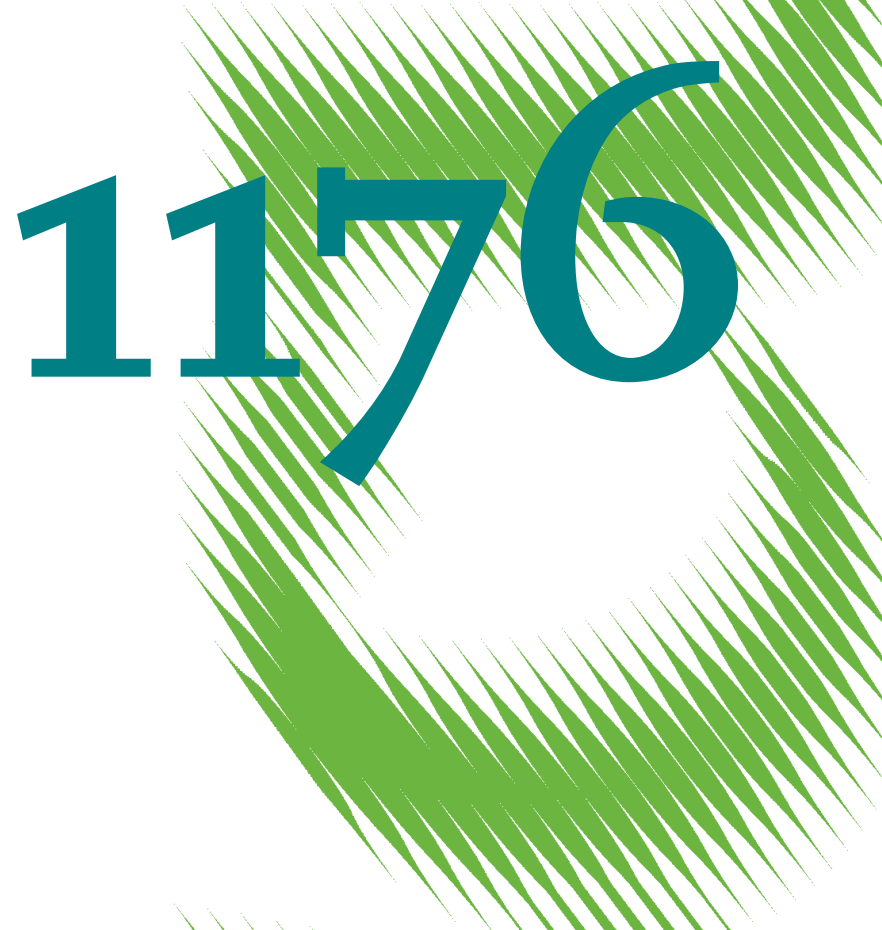

Assessing the Strength and Effectiveness of Renewable Electricity Feed-in Tariffs in European Union Countries 
Opinions expressed in this paper are those of the author(s) and do not necessarily reflect views of the institute.

IMPRESSUM

(C) DIW Berlin, 2011

DIW Berlin

German Institute for Economic Research

Mohrenstr. 58

10117 Berlin

Tel. $+49(30) 89789-0$

Fax +49 (30) $89789-200$

http://www.diw.de

ISSN print edition $1433-0210$

ISSN electronic edition 1619-4535

Papers can be downloaded free of charge from the DIW Berlin website:

http://www.diw.de/discussionpapers

Discussion Papers of DIW Berlin are indexed in RePEc and SSRN:

http://ideas.repec.org/s/diw/diwwpp.html

http://www.ssrn.com/link/DIW-Berlin-German-Inst-Econ-Res.html 


\title{
Assessing the strength and effectiveness of renewable electricity feed-in tariffs in European Union countries
}

\author{
Felix Groba ${ }^{a}$, Joe Indvik ${ }^{b}$, Steffen Jenner ${ }^{c}$
}

Abstract: In the last two decades, feed-in tariffs (FIT) and renewable portfolio standards (RPS) have emerged as two of the most popular policies for supporting renewable electricity (RES-E) generation in the developed world. A few studies have assessed their effectiveness, but most do not account for policy design features and market characteristics that influence policy strength. In this paper, we employ 1992-2008 panel data to conduct the first analysis of the effectiveness of FIT policies in promoting solar photovoltaic (PV) and onshore wind power development in 26 European Union countries. We develop a new indicator for FIT strength that captures variability in tariff size, contract duration, digression rate, electricity price, and electricity generation cost to estimate the resulting return on investment. We then regress this indicator on added RES-E capacity using a fixed effects specification. We find that FIT policies have driven solar PV and onshore wind capacity development in the EU. However, this effect is overstated without controls for country characteristics and may be concealed without accounting for the unique design of each policy. We provide empirical evidence that the interaction of policy design and market dynamics are more important determinants of RES-E development than policy enactment alone.

Keywords: Renewable energy, Feed-in tariff, Panel data models

JEL Classification: $C 23, H 23, Q 42, Q 48$

Acknowledgement: The authors would like to thank Sebastian Busch (EEG), Gabe Chan (Harvard), Jochen Diekman (DIW), Richard B. Freeman (Harvard), Claudia Kemfert (DIW), and Stephan Schindele as well as the participants of the $30^{\text {th }}$ USAEE/IAEE North America Conference in Washington D.C. for their valuable comments that substantially improved this article. Support from ICF International, the Friedrich-EbertFoundation, and the Heinrich-Böll-Foundation is gratefully acknowledged. Any remaining errors and inconsistencies are the authors' alone.

\footnotetext{
a German Institute of Economic Research, Mohrenstrasse 58, 10117 Berlin, Germany, fgroba@diw.de, Tel.: +49-30-89789-681.

b ICF International, 1725 I Street N.W., Washington, D.C. 20006, USA, jindvik@icfi.com, Tel.:+1-515-230-4665.

${ }^{\mathrm{c}}$ Harvard University, 72 Kirkland Street, Cambridge, MA 02138, USA, jenner@fas.harvard.edu, Tel.: +1-857-756-0361.
} 



\section{Introduction}

Many national, regional, and local governments have passed regulations to encourage renewable electricity (RES-E) generation in the last two decades. RES-E generation sources include biomass, geothermal energy, hydroelectric power, wave power, tidal power, solar photovoltaic, solar thermal and wind power. Motivations for regulatory support of RES-E generation include rising concerns over climate change and pollution, national security risks associated with fossil fuels, and a desire to increase the competitiveness of new energy sources in markets traditionally dominated by fossil fuels.

\subsection{Varieties of renewable energy policy design}

RES-E policies can be characterized along two regulatory dimensions. First, policies may regulate either the price of renewable electricity or the quantity produced, a distinction most famously analyzed by Weitzman (1974). Second, policies may support investment in RES-E capacity or directly subsidize generation (Haas et al. 2004, Haas et al. 2008, Menanteau et al. 2003). Policies are categorized along these dimensions in Table 1.

Table 1: Renewable energy support policies

\begin{tabular}{|c|c|c|}
\hline & Price & Quantity \\
\hline Investment & $\begin{array}{l}\text { - Investment subsidies } \\
\text { - Tax credits } \\
\text { - Low interest/soft loans }\end{array}$ & $\begin{array}{l}\text { - Tendering systems for } \\
\text { investment grants }\end{array}$ \\
\hline Generation & $\begin{array}{l}\text { - } \quad \text { Fixed price feed-in tariffs } \\
\text { - } \quad \text { Premium feed-in tariffs }\end{array}$ & $\begin{array}{l}\text { - Renewable energy portfolio } \\
\text { standards } \\
\text { - Tendering systems for long } \\
\text { term contracts }\end{array}$ \\
\hline
\end{tabular}

Table modified from Haas et al. (2008).

Two of the most popular policy types for encouraging RES-E generation in the developed world are feed-in tariffs (FIT) and quotas, often called renewable portfolio standards (RPS). RPS is a form of command-and-control quantity regulation that requires utilities to generate a certain portion of their electricity from renewable sources. It tends to promote the lowest-cost RES-E technologies, as utilities can typically choose from a variety of technologies to meet their quota requirement. In contrast, a FIT is a form of 
price regulation under which producers of RES-E sign a contract that increases the payment they receive for each kilowatt-hour generated. It provides a technology-specific subsidy to improve the competitiveness of RES-E generation relative to conventional generation sources. The effect is often to equalize attractiveness among energy technologies with different production costs. Despite these differences in design, FIT and RPS policies are similar in that (1) they are intended to promote RES-E generation beyond what would have occurred otherwise and (2) the costs of doing so are typically born by the end user.

The FIT is the most popular RES-E support scheme in European countries. However, there is considerable variety in the design of individual FIT policies (Couture and Gagnon 2010). This implies that each FIT is unique in structure and, as this paper will show, in the incentive it provides.

FIT policies may differ in one or more of the following characteristics:

- Fixed-price vs. premium tariff: A FIT may be structured as either a fixed-price tariff, which guarantees that electricity generators can sell their electricity to the grid at a set price, or a premium tariff, which adds a bonus to the wholesale market price received by generators. In the EU, Denmark and Cyprus are the only countries that have implemented a premium tariff. All other countries with a FIT employ the fixedprice design.

- Cost allocation: Under a FIT, the generator signs a contract that entitles it to feed electricity into the grid prior to any other conventional source. The difference between the tariff and the actual market price is in most countries re-distributed among end-users or paid from state budgets. To avoid overburdening end-users, Austria, Cyprus, Estonia, Ireland, Latvia, Portugal, Spain, and the Netherlands cap the total tariff value available each year.

- Contract duration: The duration over which the FIT is paid to the generator varies between policies. There is often a tradeoff between duration and magnitude. For example, the Netherlands provides a relatively high tariff for a contract duration of 10 years only, while Luxembourg provides a lower tariff for 20 years. 
- Applicable energy technologies: FIT policies in most countries support all renewable electricity technologies with the exception of large-scale hydroelectric power. However, some countries restrict FIT applicability to specific technologies. For example, France supports wind power, biomass, and solar PV only, whereas Italy focuses entirely on solar PV.

- Tariff amount: The tariff received by generators may differ in size between countries and energy technologies. Factors that influence the size of the tariff provided by a policy include generation cost, location, system size, receiving party, and the purpose of the host building.

- Digression rate: Many FIT policies have a built-in digression rate, a mechanism for reducing the tariff value according to the number of years after policy enactment a FIT contract is signed. The goal is to slowly adjust the incentive provided by the FIT, to both adapt to and incentivize cost reductions in RES-E generation over time.

Several other types of RES-E policies have emerged in the EU and U.S. in the last two decades as well. Six EU countries have introduced tradable green certificate systems. Seven countries have introduced tax incentives or investment grants. Four have implemented a tendering system, a type of quantity regulation. Denmark and Italy also augment their RES-E policies with a net-metering policy. In the U.S., quantity regulation in the form of renewable portfolio standards has emerged as the dominant policy tool at the state level, with 29 states and the District of Colombia implementing an RPS by 2011 (DSIRE 2011; Palmer et al. 2011). Worldwide, more than 80 countries employ policies to promote RES-E (REN21 2010).

\subsection{The question of RES-E development and FIT effectiveness in Europe}

Between 1990 and 2011, 23 EU member countries implemented a feed-in tariff to support solar PV or onshore wind development. Table 2 displays the years of enactment for major RES-E policy types in Europe. Policy enactment is skewed over time: some countries such as Germany and Italy adopted RES-E policies very early, but most have done so within the last decade. 
Table 2: Years of RES-E policy enactment in EU 27 countries from 1990 to 2011

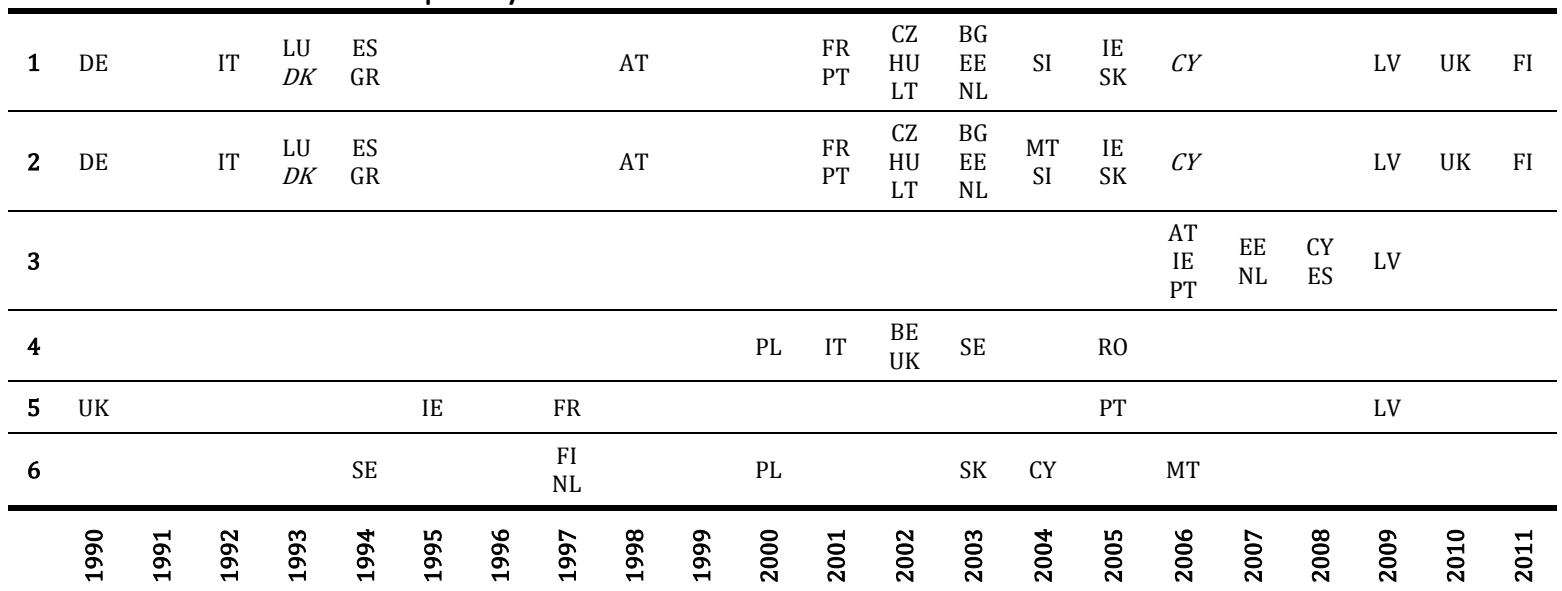

Each row represents a policy type. Italics designate premium FIT policies. (1) Fixed or premium FIT for onshore wind, (2) fixed or premium FIT for solar PV, (3) first cap introduced, (4) quota scheme, (5) tendering scheme, (6) tax incentive/investment grant. Source: Res-legal (2011), Ragwitz et al. (2011), and REN21 (2010).

During this same time period, RES-E generation capacity in EU 27 countries has developed rapidly and unevenly. Figure 1 displays trends in cumulative non-hydro RES-E generation capacity in EU countries. Previous studies have examined these dividing paths using an array of macroeconomic, ecological and socio-economic factors. A few quantitative studies have assessed the effectiveness of RES-E policies, but this is an area of surprisingly sparse research.

Figure 1: Total non-hydroelectric RES-E electricity generation capacity in EU 27 countries

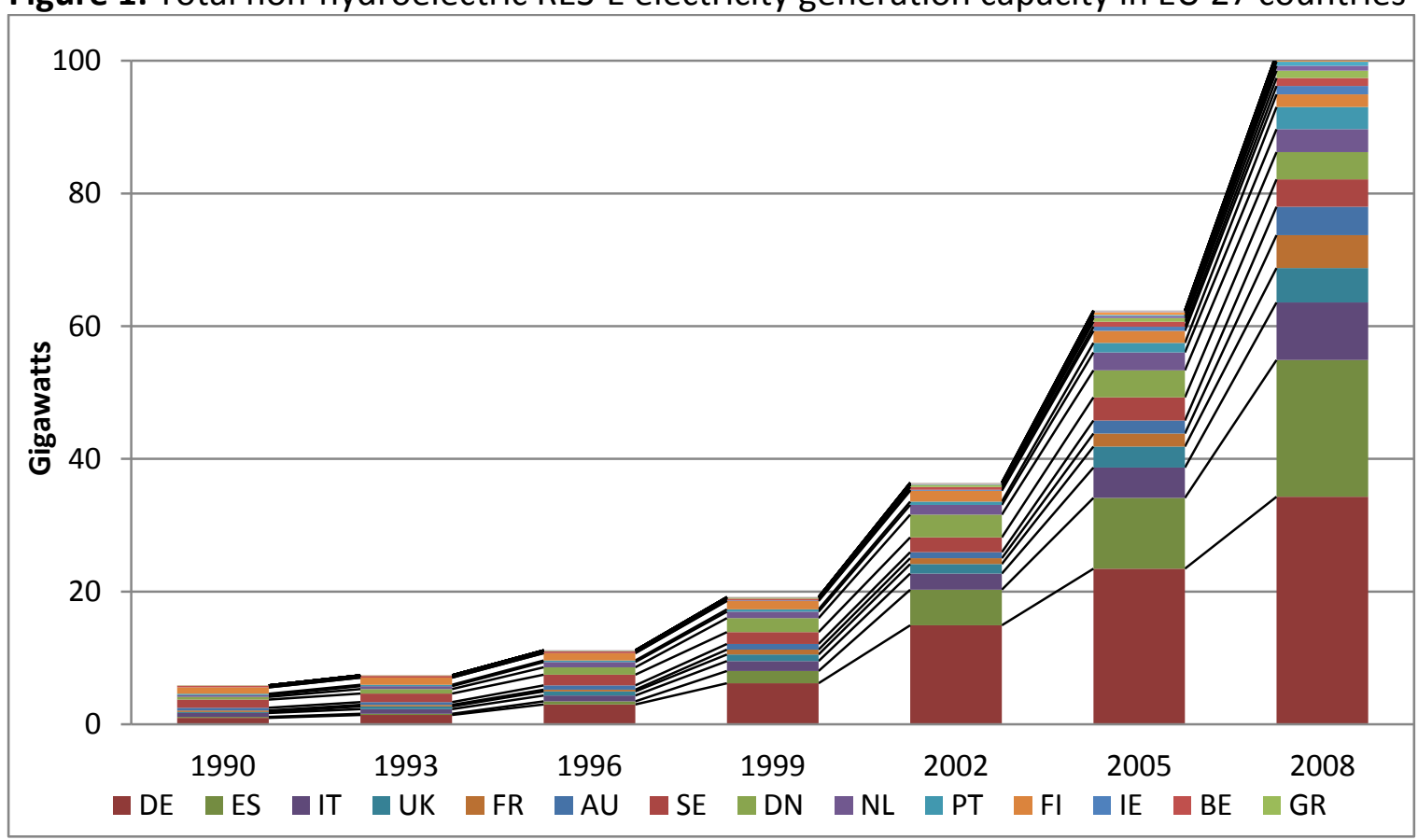

Countries are stacked in order of total installed capacity in 2008. Source: EIA (2011) 


\subsection{Research question and contribution}

In light of the differences in both RES-E development and FIT enactment between countries and over time, a key question for policymakers is whether FIT policies have actually increased RES-E generation capacity beyond what would have occurred in their absence. In this paper, we develop the first rigorous econometric analysis of FIT effectiveness in Europe to date. The primary contribution of our paper is to develop an indicator for the strength of FIT policies that takes into account differences in policy design. Specifically, we capture heterogeneity in tariff size, contract duration, digression rate, electricity wholesale price, and electricity generation cost to construct a measure of the return-on-investment (ROI) provided by each policy. We develop a technologyspecific fixed-effects regression model to test the significance of this indicator using historical data on solar PV and onshore wind power in the EU. The model controls for fixed country-level characteristics that may be correlated with both policy implementation and RES-E development.

This paper improves and expands on the existing literature in three key ways. First, it focuses on a policy type and a region that have been largely ignored in previous econometric studies. Second, it accounts for unique policy design features that have been largely ignored in econometric analyses of RES-E policies in general. Third, it provides a detailed literature review and summary of trends in econometric RES-E policy analysis, with a focus on methodology.

We find that FIT policies are a major driver of solar PV and onshore wind capacity development. However, this effect is overstated without controlling for country characteristics and may not be observed at all without accounting for the unique design of each policy.

The remainder of the article is organized as follows. Section two provides a literature review on econometric RES-E policy assessments with a specific focus on the models used. Section three presents our empirical framework, including our new indicator that quantifies ROI for FIT policies, regression specification, selection of controls, and data. Section four provides regression results that we discuss in section five. 


\section{Literature Review}

Literature on the role of policy in the development of renewable energy sources is vast. However, the majority of research takes a normative or descriptive approach to outlining the factors that influence RES development. Several case studies (del Río González and Gual 2007, del Río González 2008, Haas et al. 2011, Lesser and Su 2008, Lipp 2007) and other qualitative evaluation techniques have suggested that FIT policies are an important element in explaining the success of RES-E development in Europe.

Rigorous empirical studies of renewable energy policy effectiveness are less common. Studies with methods or results relevant to our analysis are summarized in Table 3. However, to our knowledge, the present paper is the first study to apply econometric methods to the problem of FIT effectiveness is Europe.

Most econometric studies assessing the effectiveness of renewable energy policies to date have focused on state-level policies in the United States, particularly RPS. However, several lessons can be learned from recent developments in the study of RPS policies and applied to an analysis of FIT policies in Europe. Studies that examine the drivers of RES-E development can be divided into three groups: (1) those that employ cross-sectional specifications, (2) those that use panel data to control for state-level characteristics, and (3) more nuanced analyses that use complex dependent and/or independent variables to articulate differences in policy design or policy responsiveness.

The first group (Menz and Vachon 2006, Adelaja and Hailu 2008) employs pooled cross-section regressions to look at the impact of policy variables (usually a binary variable or simple numeric indicator such as the dollar value of a tax credit) on RES-E capacity development. Alegappan et al. (2011) rely on descriptive statistics only. These studies find a strong positive correlation between RPS (and some other policies) and renewable energy development. However, their specifications do not control for statelevel characteristics or time trends that may be correlated with both policy implementation and RES-E development, so this relationship cannot be interpreted as causal. 
Table 3: Relevant empirical studies of renewable energy policy effectiveness

\begin{tabular}{|c|c|c|c|c|c|c|}
\hline & Sample & \begin{tabular}{|l|} 
Time- \\
frame
\end{tabular} & \begin{tabular}{|l|}
$\begin{array}{l}\text { Dependent } \\
\text { Variable }\end{array}$ \\
\end{tabular} & \begin{tabular}{|l|}
$\begin{array}{l}\text { Technology- } \\
\text { specific? }\end{array}$ \\
\end{tabular} & Specification & Policy variables \\
\hline \begin{tabular}{|l|} 
Menz/ \\
Vachon \\
(2006)
\end{tabular} & 37 U.S. states & $\begin{array}{l}1998- \\
2003\end{array}$ & $\begin{array}{l}\text { Cumulative } \\
\text { Capacity }\end{array}$ & Wind & $\begin{array}{l}\text { Cross-section, } \\
\text { OLS }\end{array}$ & \begin{tabular}{|l|} 
Binaries: RPS, \\
GDR, MGPO, BPF, \\
RC
\end{tabular} \\
\hline Carley (2009) & 48 U.S. states & $\begin{array}{l}1998- \\
2006\end{array}$ & $\begin{array}{l}\text { Cumulative } \\
\text { Generation } \\
\% \text { RES-E } \\
\text { Generation }\end{array}$ & No & FE, FEVD & \begin{tabular}{|l|} 
Binaries: \\
RPS; \\
Nominal: regional \\
RPS \\
\end{tabular} \\
\hline $\begin{array}{l}\text { Yin/ } \\
\text { Powers } \\
\text { (2009) }\end{array}$ & 50 U.S. states & $\begin{array}{l}1993- \\
2006\end{array}$ & $\begin{array}{l}\% \text { RES-E } \\
\text { Generation }\end{array}$ & No & FE & $\begin{array}{l}\text { Binaries: RPS, } \\
\text { MGPO, PBF, NM; } \\
\text { Nominal: RPS } \\
\text { through } \\
\text { INCRQMSHARE } \\
\end{array}$ \\
\hline $\begin{array}{l}\text { Marques } \\
\text { et al. (2010) }\end{array}$ & $\begin{array}{l}24 \text { European } \\
\text { states }\end{array}$ & $\begin{array}{l}1990- \\
2006\end{array}$ & $\begin{array}{l}\text { \% RES of total } \\
\text { primary energy } \\
\text { supply }\end{array}$ & No & FE, FEVD & Binary: EU2001 \\
\hline $\begin{array}{l}\text { Alagappan } \\
\text { et al. (2011) }\end{array}$ & $\begin{array}{l}14 \\
\text { transmission } \\
\text { companies }\end{array}$ & 2010 & $\begin{array}{l}\% \text { RES-E } \\
\text { Capacity }\end{array}$ & No & $\begin{array}{l}\text { Descriptive } \\
\text { statistics }\end{array}$ & $\begin{array}{l}\text { Binaries: FIT, MR, } \\
\text { type of } \\
\text { transmission } \\
\text { planning }\end{array}$ \\
\hline $\begin{array}{l}\text { Delmas } \\
\text { et al. (2011) }\end{array}$ & 650 utilities & $\begin{array}{l}1998- \\
2007\end{array}$ & $\begin{array}{l}\text { Cumulative } \\
\text { Capacity }\end{array}$ & No & $\begin{array}{l}\text { Tobit and } \\
\text { logit }\end{array}$ & $\begin{array}{l}\text { Probabilities: RPS, } \\
\text { MGPO, GDR; } \\
\text { number of tax } \\
\text { incentives }\end{array}$ \\
\hline $\begin{array}{l}\text { Marques } \\
\text { et al. (2011) }\end{array}$ & $\begin{array}{l}24 \text { European } \\
\text { states }\end{array}$ & $\begin{array}{l}1990- \\
2006\end{array}$ & $\begin{array}{l}\text { \% RES to total } \\
\text { primary energy } \\
\text { supply }\end{array}$ & No & Quantile & None \\
\hline $\begin{array}{l}\text { Shrimali/ } \\
\text { Kneifel } \\
\text { (2011) }\end{array}$ & 50 U.S. states & $\begin{array}{l}1991- \\
2007\end{array}$ & $\begin{array}{l}\% \text { RES-E } \\
\text { Capacity }\end{array}$ & \begin{tabular}{|l} 
Wind, \\
biomass, \\
geothermal, \\
solar
\end{tabular} & FE & $\begin{array}{l}\text { Binaries: RPS, GPP, } \\
\text { MGPO, PBF }\end{array}$ \\
\hline This article & $\begin{array}{l}26 \mathrm{EU} \\
\text { countries }\end{array}$ & $\begin{array}{l}1992- \\
2008\end{array}$ & $\begin{array}{l}\text { Cummulative } \\
\text { Capacity } \\
\text { Added Capacity }\end{array}$ & $\begin{array}{l}\text { Onshore } \\
\text { wind, } \\
\text { solar PV }\end{array}$ & FE & $\begin{array}{l}\text { Binaries: FIT, RPS, } \\
\text { TEN, TI, EU2001 } \\
\text { Nominal: } \\
\text { INCRQMSHARE; } \\
\text { ROI }\end{array}$ \\
\hline \multicolumn{4}{|c|}{$\begin{array}{l}\text { EU2001: EU 2001/EC/77 Directive } \\
\text { FEVD: fixed effect vector decomposition model } \\
\text { FIT: feed-in-tariff } \\
\text { FE: fixed effect panel estimation } \\
\text { GPP: green power purchasing } \\
\text { MGPO: mandatory green power option }\end{array}$} & \multicolumn{3}{|c|}{$\begin{array}{l}\text { MR: market restructuring } \\
\text { NM: net metering PBF : public benefits fund } \\
\text { RC: retail choice } \\
\text { RPS: renewable portfolio standard } \\
\text { TEN: tendering system } \\
\text { TI: tax incentive }\end{array}$} \\
\hline
\end{tabular}

The second group (Carley 2009, Delmas 2011, Marques et al. 2010, Shrimali and Kneifel 2011) provides empirical evidence to support this concern. These studies use fixed-effects regression models or other strategies to reduce omitted variables bias from state characteristics that are correlated with both policy implementation and renewable 
energy deployment. They suggest a less certain relationship between RPS policies and deployment. For example, Carley (2009) finds that RPS implementation does not predict the percentage of energy generation from renewable sources, though the number of years a state maintains an RPS is a significant determinant of total renewable energy capacity development. Shrimali and Kneifel (2011) find that RPS policies actually appear to reduce the penetration of some RES-E technologies and overall RES-E capacity, while they increase the penetration of others. These results call into question the effectiveness of RPS policies once non-policy state characteristics have been controlled for.

The third group (Marques et al. 2011, Yin and Powers 2009) uses more nuanced model specifications to better capture the complexity of RES-E development. Marques et al. (2011) apply a quantile regression approach to analyze the drivers of renewable energy deployment in European Union countries, finding that responsiveness to economic and social drivers varies in magnitude, significance, and sometimes direction between countries with different initial levels of renewable energy penetration. However, Marques et al. (2011) do not incorporate any policy variables. Yin and Powers (2009) make a key contribution to the debate by addressing policy design heterogeneity in state-level RPS policies in the U.S. They develop a new quantitative measure of RPS stringency that takes into account policy design features that differ by state. Applying this new measure within a fixed-effects specification, they find that RPS policies have had a significant and positive effect on renewable energy deployment. Most importantly, they verify that this effect would not be observed if differences in policy design are ignored, as done in studies that use binary policy variables only.

The two primary analyses of RES-E development drivers in Europe are provided by Marques et al. (2010; 2011). In the first paper, they use a panel FEVD model on a sample of 24 European countries from 1990 to 2006 to estimate the effect of general political and socioeconomic factors on the renewable energy percentage of total electricity generation. The empirical approach of the second paper was discussed above. These papers find that the fossil fuel industry lobby is a negative driver of development, while energy dependency, energy consumption, and the European Union Directive 2001/77/EC - which created mandatory RES-E targets for EU member countries-are 
positive drivers. However, neither of these studies specifically assesses the impact of individual policy types.

\section{Empirical Framework and Data}

The primary objective of this paper is to assess the effectiveness of FIT policies in promoting renewable electricity capacity development in the EU.

Leveraging lessons learned from the above studies, we make three key contributions. First, we apply a rigorous econometric framework to the problem of FIT effectiveness in Europe. We assemble country-specific data at a technology-specific level for solar PV and onshore wind capacity for the period from 1992 to 2008 in 26 European Union countries. ${ }^{1}$ Thus, we can not only test for the impact of political and socioeconomic variables on RES-E development as done by Marques et al. (2010; 2011), but we can also assess the effectiveness of FIT policies specifically. Second, we use a fixed-effects panel data approach to control for unobserved state-level characteristics that may influence both policy implementation and renewable energy development. Third, we develop a new statistical indicator for feed-in tariffs-similar to that developed by Yin and Powers (2009) for RPS - that accounts for policy design elements that may influence policy strength.

\subsection{Dependent variable selection}

A review of the literature reveals several possible dependent variables to represent RES-E development. The options differ along two dimensions: (1) whether development includes nameplate capacity, actual generation, or total energy supply and (2) whether development is represented as a cumulative total, yearly change, or a ratio of renewable to conventional energy.

In the first case, we use capacity instead of generation or supply to reflect the investment decision as purely as possible. Capacity development tracks with RES-E investment without being biased by forces the investor cannot foresee or control. While RES-E generation is largely determined by installed capacity, it is also affected by weather, equipment performance, technical problems, and other factors. In other

\footnotetext{
${ }^{1}$ The sample consists of 26 out of the 27 EU member states. We excluded Malta due to incomplete data.
} 
words, generation determines the actual return on investment while capacity reflects the expected return on investment. Since our goal is to examine links between FIT policies and the decision to invest in solar PV or wind installations (rather than the actual value derived from those installations), capacity is the most relevant metric.

In the second case, we use annual added capacity. Added capacity is preferable to the ratio of renewable electricity to total electricity capacity for two reasons. First, while feed-in tariffs are designed to increase RES-E capacity, they are not explicitly designed to increase the share of RES-E relative to other electricity sources (unlike RPS policies, for example). In other words, RES-E ratio is not technically a good metric for the "effectiveness" of a feed-in tariff. Second, using a ratio introduces additional statistical variability that is not relevant to our analysis. Other types of generation capacity may be added or lost due to forces unrelated to RES-E development.

Added capacity is also preferable to cumulative capacity because we want the effect of a policy to be isolated from cumulative development of capacity before an investment is made. A FIT contributes to the return on investment associated with an RES-E system installed in a given year. The value added by the FIT is set for that year through the duration of the contract. Therefore, the investor makes his or her decision on the basis of this year's FIT and this year's cost, as well as anticipated future costs. FIT levels and capacity development in previous years are unlikely to affect the individual investor's decision. In order to measure the marginal effect of a FIT policy in a given year, the effect must be isolated from past trends. The use of added capacity as the dependent variable fulfills this requirement. This has the effect of controlling for trends in total capacity over time.

Finally, we use technology-specific capacity data because FIT policies tend to be structured differently depending on the energy technology to which they apply. We conduct separate regressions for solar PV and onshore wind, allowing us to estimate the effect of technology-specific FIT policies on technology-specific capacity development. With the exception of Menz and Vachon (2006) and Shrimali and Kneifel (2011), previous studies have used total RES-E data or the renewable energy share of total energy supply and therefore do not distinguish between the relative contribution of different energy technologies. We obtained capacity data from the UN Energy Statistics Database (2011). 


\subsection{Assessing the strength of feed-in tariffs}

Behavioral research sheds some light on the link between FIT policies and RES-E development. Burer and Wustenhagen (2009) surveyed European and North American venture capital investors to determine their preferred policy environment for investing. They found that investors prefer feed-in tariffs above any other policy types, largely because they reduce investment risk more than other policies. Building on Held (2009), Masini and Menichetti (2010) also employ a survey to examine behavioral factors that influence investments in energy systems. Their study demonstrates the key importance of clear policy signals in driving investment and finds that investors strongly favor feed-in tariffs over any other RES-E policy. In addition, they find that investors consider tariff size and contract duration of feed-in-tariffs almost equally important. While these authors take a qualitative ex-ante approach, we complement and verify their work with a quantitative ex-post approach. They ask investors to what extent the political and market environment shapes investment decisions; we rigorously quantify and test the significance of those drivers in actual RES-E deployment.

The investment incentive provided by feed-in tariffs varies significantly depending on how each policy is designed and the market in which it operates. Key factors are the size of the tariff paid to the electricity producer, wholesale electricity price, the length of a contract agreement under a tariff, and the cost of RES-E electricity production. In order to take these factors into account, we developed a new indicator for the return-oninvestment (ROI) faced by a potential investor in RES-E. For energy technology $i$, in country $s$, in year $t$, ROI is defined as:

$$
\mathrm{ROI}_{\mathrm{ist}}=\frac{\mathrm{FIT}_{\mathrm{ist}} * \mathrm{CT}_{\mathrm{ist}}+\mathrm{P}_{\mathrm{st}} * \mathrm{LT}_{\mathrm{it}}-\mathrm{CT}_{\mathrm{ist}}-\mathrm{ACOE}_{\mathrm{ist}} * \mathrm{LT}_{\mathrm{it}}}{\mathrm{ACOE}_{\mathrm{ist}} * \mathrm{LT}_{\mathrm{it}}}
$$

where $\mathrm{FIT}_{\text {ist }}$ is the price received by a producer for electricity sold to the grid under a FIT contract (in Eurocents/kWh). For fixed-price tariffs, this is the amount of the tariff. For premium tariffs, this is the market price of electricity plus the bonus. This value also takes into account digression rates where applicable-i.e. FIT $_{\text {ist }}$ is reduced depending on the number of years after policy enactment $t$ occurs. $\mathrm{CT}_{\text {ist }}$ is the duration of a FIT contract (in years) established in year $t$. $\mathrm{P}_{\mathrm{st}}$ is the wholesale electricity price (in Eurocents/kWh) in year $t$. While the tariff size is fixed for the duration of the contract, the wholesale 
electricity price is subject to fluctuation. Therefore, investors in RES-E capacity must deal with uncertainty in estimating future revenues. We assume that the investor will expect the wholesale electricity price to remain stable at $P_{s t}$ over the lifetime of capacity installed in year $t$. $L T_{\text {it }}$ is the expected lifetime (in years) of a solar panel or wind turbine constructed in year $t . \mathrm{ACOE}_{\text {ist }}$ is the average cost of electricity production for capacity built in year $t$ (in Eurocents/kWh).

Intuitively, the indicator represents the return on investment associated with RESE capacity installed in year $t$. The numerator represents total profit (revenue minus cost) received by a RES-E producer for generating one $\mathrm{kWh}$ per year over the lifetime of a panel or turbine installed under a FIT contract in year $t$. During the FIT contract, the producer receives revenue of $\mathrm{FIT}_{\text {ist. }}$. After the contract has expired, revenue drops to the wholesale market price until the end of the capacity's lifetime. The denominator represents the total lifetime cost of producing one kWh annually. Therefore, ROI is the ratio of profit to cost per kWh over the lifetime of capacity installed in year $t$. We assume constant capacity utilization across the entire panel. For years in which no FIT policy has been enacted, $C T=0$ and $\mathrm{ROI}$ represents the return on investment received by RES-E producers in the absence of a FIT. Overall, ROI is a more nuanced indicator of the true investment incentive provided by a FIT, as compared to traditional binary policy variables that are simply "on" if a policy is in place and "off" if it is not.

In order to isolate the effect of FIT policies from non-policy components of return on investment, we also split the ROI indicator into two pieces. ROI_ $1_{\text {ist }}$ represents return on investment in the presence of a FIT policy. This indicator is identical to the standard ROI indicator, except that it takes the value 0 for any country-years in which a FIT is not in place. This is mathematically defined as:

$$
\begin{aligned}
& \text { ROI_1 } \text { ist }=\frac{\mathrm{FIT}_{\text {ist }} * \mathrm{CT}_{\mathrm{ist}}+\mathrm{P}_{\mathrm{st}} * \mathrm{LT}_{\mathrm{it}}-\mathrm{CT}_{\mathrm{ist}}-\mathrm{ACOE}_{\mathrm{ist}} * \mathrm{LT}_{\text {it }}}{\mathrm{ACOE}_{\mathrm{ist}} * \mathrm{LT}_{\mathrm{it}}}, \text { if } \mathrm{FIT}_{\text {ist }}>0 \\
& 0 \text {, } \\
& \text { if } \text { FIT }_{\text {ist }}=0
\end{aligned}
$$

$\mathrm{ROI} \mathrm{O}_{\text {ist }}$ is a second indicator that represents return on investment when no policy is present. For years in which a FIT is in place, it takes the value 0 . Therefore: 


$$
\text { ROI_0 } \text { ist }=\begin{array}{ll}
\frac{\mathrm{P}_{\text {st }} * \mathrm{LT}_{\text {it }}-\mathrm{ACOE}_{\text {ist }} * \mathrm{LT}_{\text {it }}}{\mathrm{ACOE}_{\text {ist }} * \mathrm{LT}_{\text {it }}}, & \text { if } \mathrm{FIT}_{\text {ist }}=0 \\
0, & \text { if } \mathrm{FIT}_{\text {ist }}>0
\end{array}
$$

Including these indicators allows us to separately analyze those country-years in which a FIT is and is not present within the same regression model. The effect is to partially parse out policy-driven changes in ROI from those changes attributable to other factors.

\subsection{Data}

Constructing the ROI indicator requires us to assemble 1992-2008 data for each of its components. For both solar PV and onshore wind, we gratefully received technical support from the Energy Economics Group at Vienna University of Technology. Their GreenX toolbox provided real policy data and real cost data for the time period from 2006 to 2009 as well as projections for 2010 to 2020 . The GreenX model has also been used by Fraunhofer ISI (Sensfuss and Ragwitz 2007), the European Commission, and others. If GreenX (EEG 2009a) did not sufficiently cover the necessary data, information from RES-Legal (2011), REN21 (2010), the IEA Policies and Measures Database (2011a), and Ragwitz et al. $(2009 ; 2011)$ was used to close the gaps. Data on the average cost of electricity generation from solar PV and onshore wind was taken from Schilling (2009). ${ }^{2}$

In the majority of cases, FIT policies pay different tariffs to different technologies. While other studies have neglected this heterogeneity, this study accounts for the different levels of tariffs by focusing on two technologies separately. Still, the model cannot cover the complete continuum of heterogeneity in FIT policies. The majority of countries pay a fixed tariff per kWh to the producer of electricity from wind onshore systems. Solar PV FIT schemes are more diverse, as tariff size varies with the size of the installation and its ownership. We follow GreenX by relying on the mean value of the PV tariff across all size, location and ownership categories, recognizing that some information is lost in order to gain feasibility.

Especially in the years during the global financial crisis, many governments across the EU modified their FIT schemes by scaling down their size. Most strikingly, Spain

\footnotetext{
${ }^{2}$ The cost data from GreenX (EEG 2009a) served as a robustness check. There have not been major differences in the outcome. We decided in favor of the Schilling (2009) data because GreenX (EEG 2009a) did not provide cost data for a few years and countries. Further research may use the GreenX toolbox or similar packages to introduce further variation in the ROI indicator.
} 
capped the FIT budget in 2008 and 2009, a change which was concurrent with reduced capacity development in Spain and caused at least 15 investors to sue the Spanish government (Morales and Sills 2011). As shown in Table 2, seven other countries capped their FIT policies, allowing for early runs on FIT contracts early in the year while keeping annual new installations under control. The other countries simply maintained the digression rates that were already part of the FIT legislation. Ragwitz et al. (2009) provide an excellent summary of these policy changes. ${ }^{3}$

Figure 2 presents calculated ROI values for each country in our sample and compares them with annual added RES-E capacity of solar PV and wind onshore.

Figure 2: Added capacity and ROI values for 26 EU member countries, 1992 to 2008

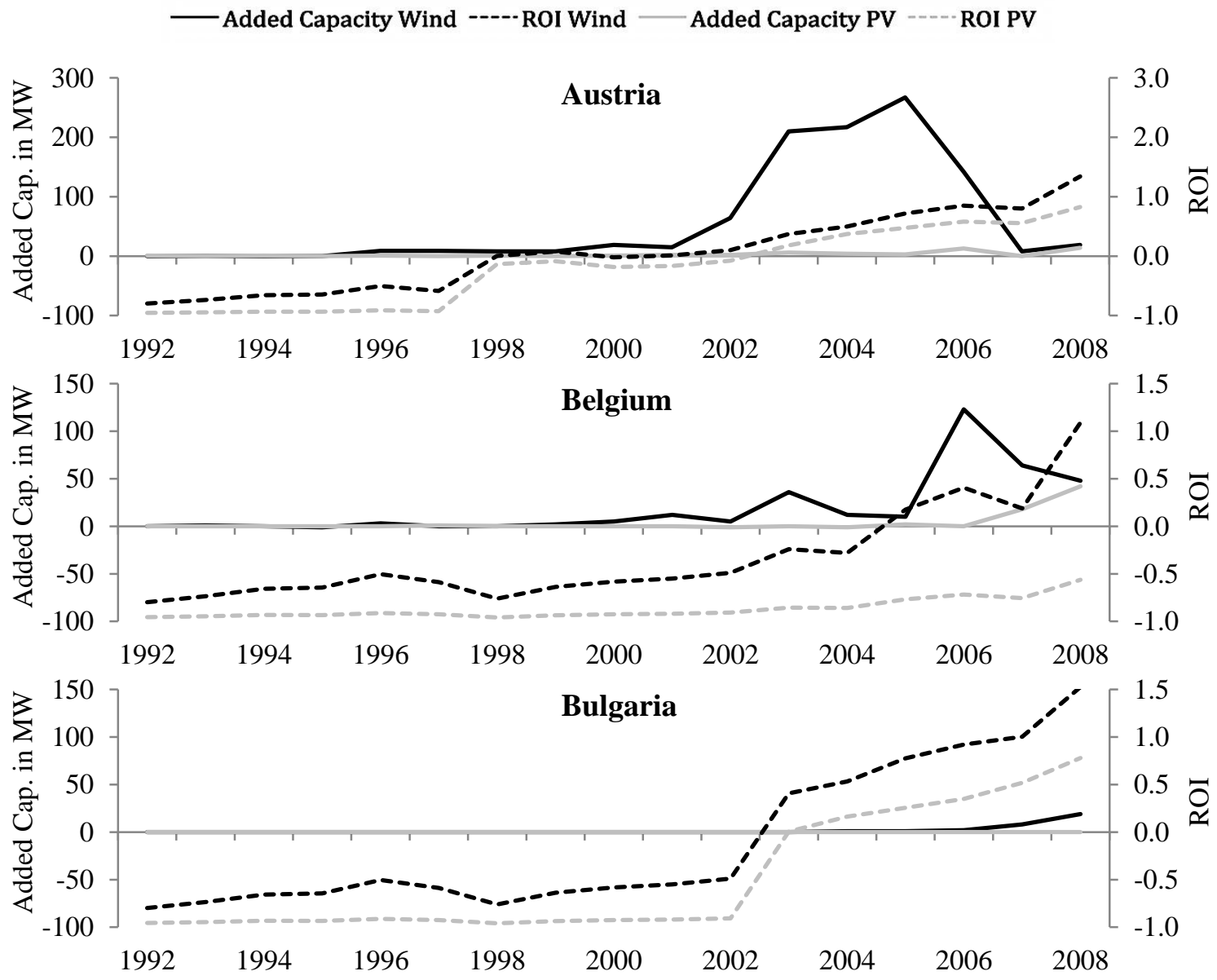

\footnotetext{
${ }^{3}$ We expect that we could not account for every change to FIT policies. Therefore, we welcome further research from other scholars or data support from policymakers to make this analysis more accurate.
} 

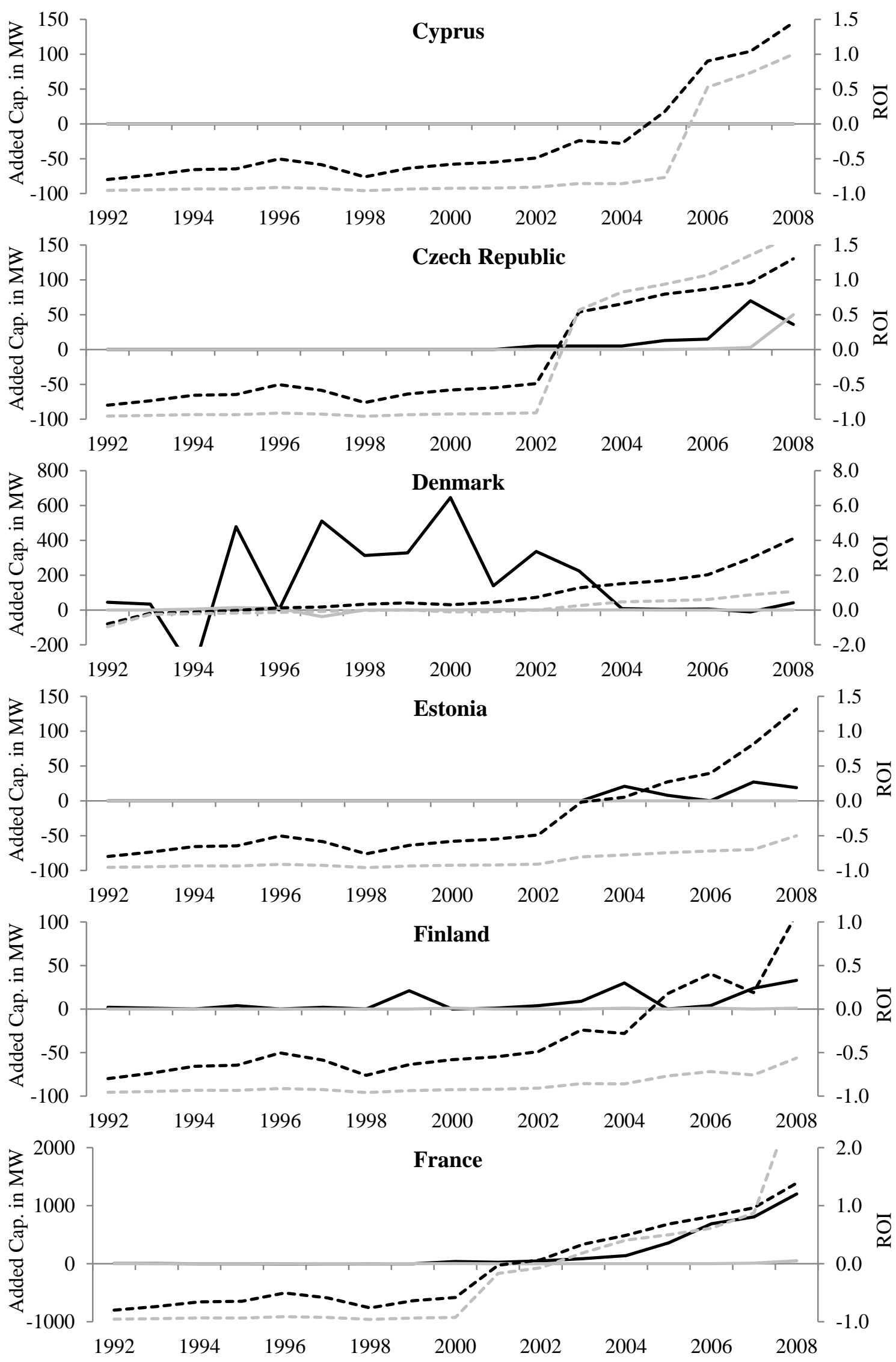

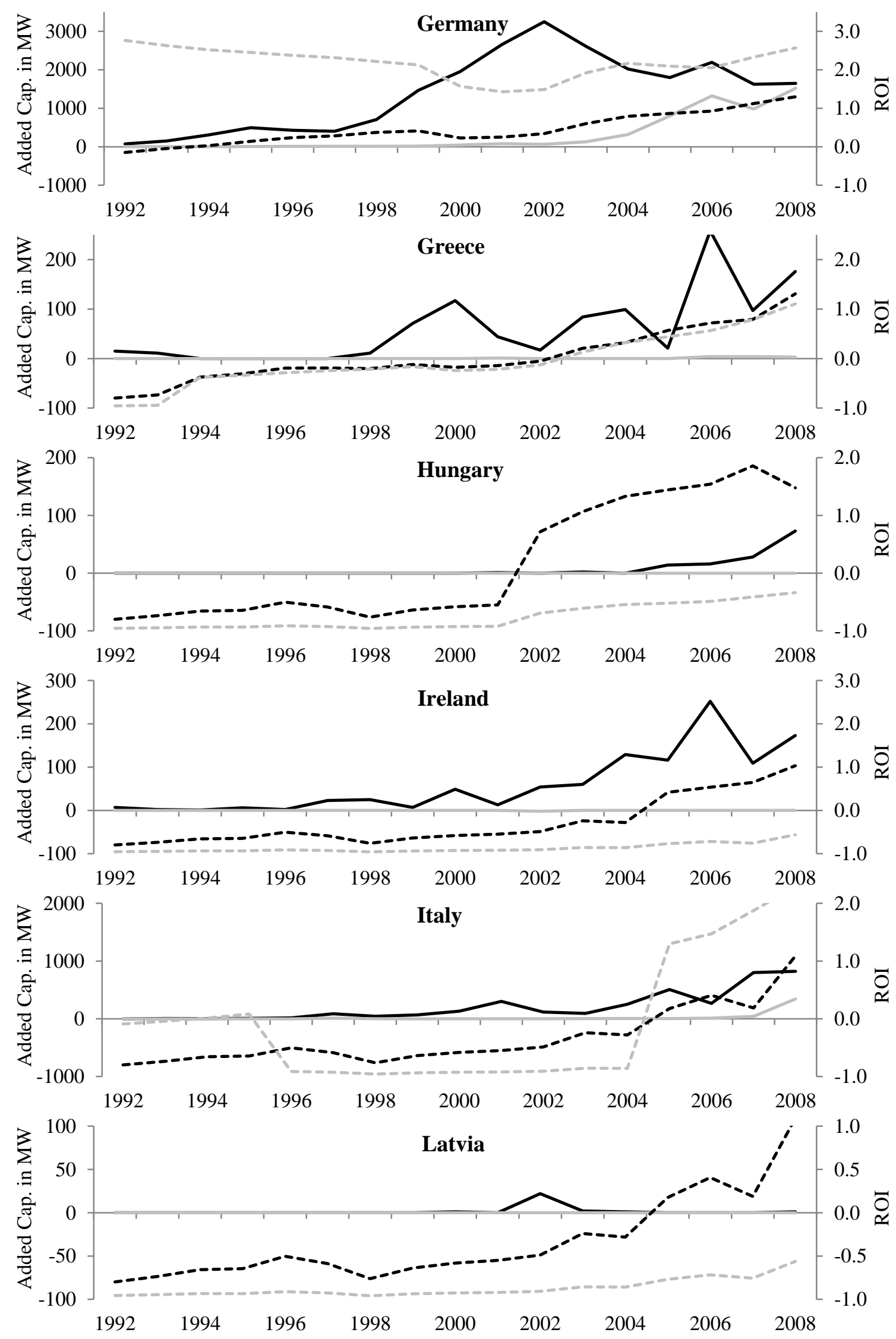

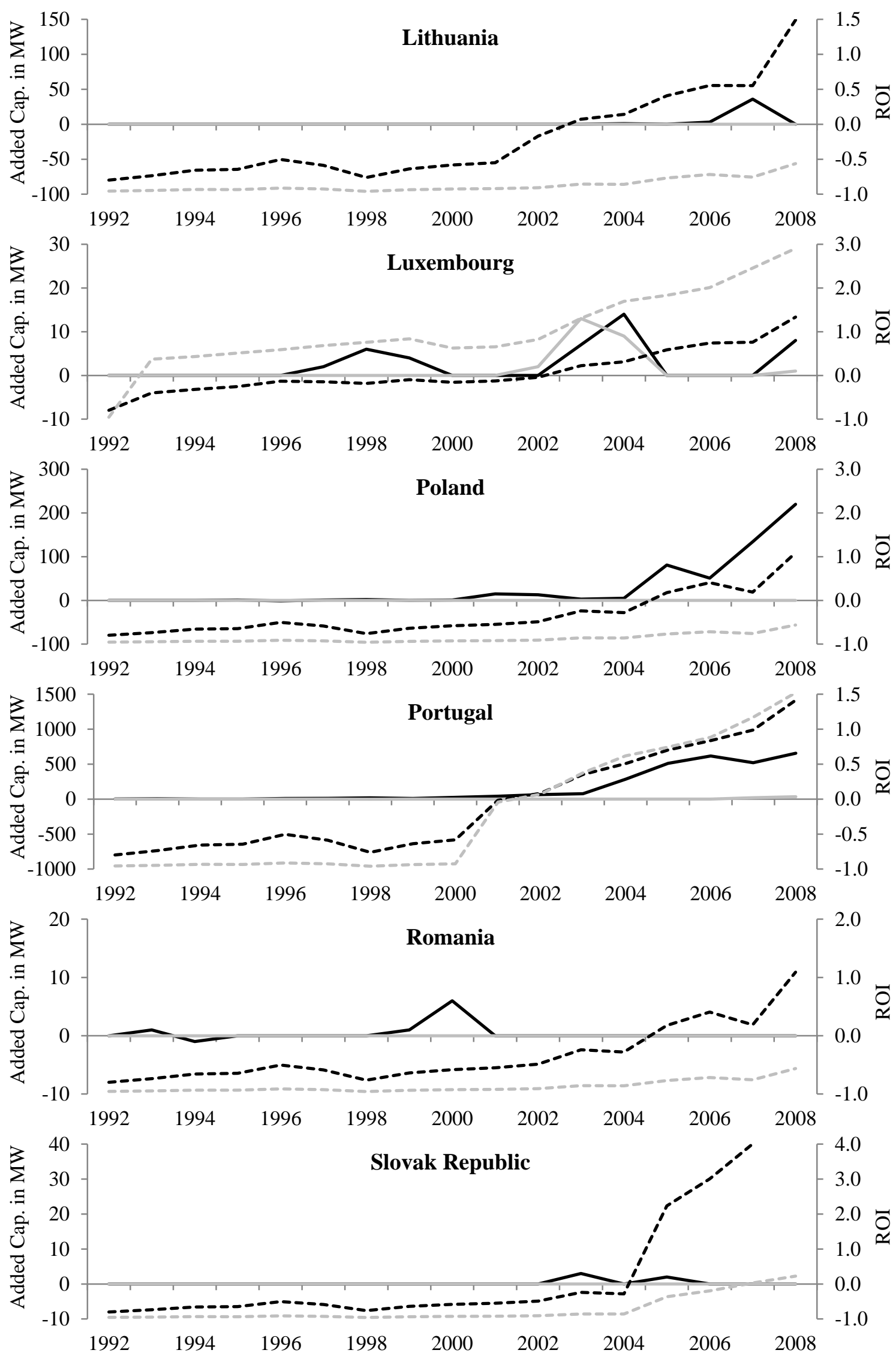

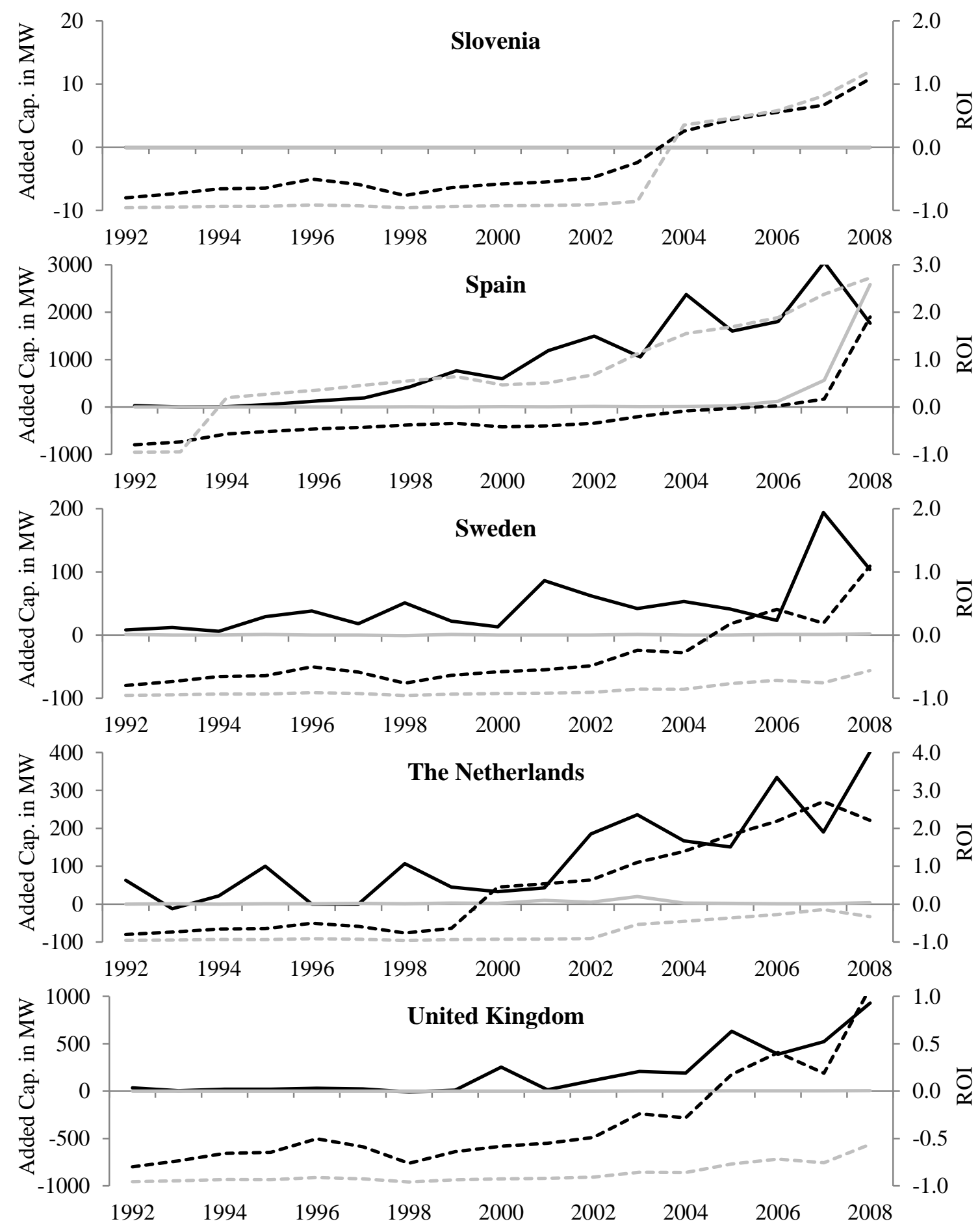

\subsection{Additional explanatory variables}

We include the "incremental percentage requirement" variable (INCRQMTSHARE ${ }_{s t}$ ), originally developed by Yin and Powers to assess the effectiveness of state-level RPS policies in the U.S. This indicator represents "the mandated increase in renewable generation in terms of the percentage of all generation" (Yin and Powers 2009: 1142). 
The indicator calculates the difference between the policy-determined nominal share of RES-E required and the existing RES-E sales that are already eligible to meet the quota, while also taking into account the portion of capacity over which the RPS has jurisdiction. The ratio of the required/existing gap to the total annual electricity sales covered by the quota yields the incremental percentage requirement. We calculated this indicator for the EU countries that employ a quota system. In 2009, Sweden had the strongest quota policy with an ICRQMTSHARE of $14.6 \%$. Other countries, such as Poland and Belgium, have indicators close to zero, implying that that their quotas are close to being attained and are unlikely to provide much pressure for additional RES-E generation capacity.

As has been outlined above, tax credits and investment loans are price-driven policies to promote investment in RES-E. Tendering schemes are quantity regulations also supporting RES-E. We control for these policies by incorporating binary codes that equal 1 if a policy is in place and 0 if it is not.

The remaining control variables are taken from the literature and are outlined in Table 4. Marques et al. (2011) provide the most sophisticated analysis of socioeconomic variables driving RES-E development in Europe to date. Unlike many previous studies, they include controls for GDP and the relative contribution of conventional energy sources to the overall fuel mix. In order to produce comparable results, we apply the controls used by Marques et al. (2011).

Carley (2009) illustrates the importance of controlling for GDP per capita, finding that is has a strong positive impact on RES-E generation. Also following Shrimali and Kneifel (2010), we expect higher GDP per capita to support development of RES-E. We expect that wealthier countries will possess to a greater degree the technological expertise, infrastructure, and risk tolerance to invest in more expensive RES-E technologies.

We also expect the total land area of a country to have a positive impact on deployment of RES-E. Larger countries will, on average, contain more suitable land for RES-E installations. Following Marques et al. (2010; 2011), we incorporate this variable into our cross-sectional regressions, though it is dropped from fixed-effects regressions because it is constant over time. 
Table 4: Controls specification

\begin{tabular}{|c|c|c|c|c|}
\hline Name & Description & Unit & Source & Also used by \\
\hline $\begin{array}{l}\text { Nuclear } \\
\text { share }\end{array}$ & $\begin{array}{l}\text { Natural logarithm of nuclear to total } \\
\text { electricity generation ratio }\end{array}$ & $\%$ & $\begin{array}{l}\text { Eurostat } \\
(2011)\end{array}$ & $\begin{array}{l}\text { Marques et al. (2010; } \\
\text { 2011) }\end{array}$ \\
\hline Oil share & $\begin{array}{l}\text { Natural logarithm of diesel and crude } \\
\text { oil to total electricity generation ratio }\end{array}$ & $\%$ & $\begin{array}{l}\text { Eurostat } \\
(2011)\end{array}$ & $\begin{array}{l}\text { Marques et al. (2010; } \\
\text { 2011) }\end{array}$ \\
\hline $\begin{array}{l}\text { Natural gas } \\
\text { share }\end{array}$ & $\begin{array}{l}\text { Natural logarithm of natural gas to } \\
\text { total electricity generation ratio }\end{array}$ & $\%$ & $\begin{array}{l}\text { Eurostat } \\
(2011)\end{array}$ & $\begin{array}{l}\text { Marques et al. (2010; } \\
\text { 2011) }\end{array}$ \\
\hline Coal share & $\begin{array}{l}\text { Natural logarithm of coal and lignite } \\
\text { to total electricity generation ratio }\end{array}$ & $\%$ & $\begin{array}{l}\text { Eurostat } \\
(2011)\end{array}$ & $\begin{array}{l}\text { Marques et al. (2010; } \\
\text { 2011) }\end{array}$ \\
\hline $\begin{array}{l}\text { GDP per } \\
\text { capita }\end{array}$ & $\begin{array}{l}\text { Natural logarithm of GDP per capita, } \\
\text { PPP }\end{array}$ & $\begin{array}{l}\text { constant } \\
2005 \text { int. } \\
\text { USD }\end{array}$ & $\begin{array}{l}\text { World Bank } \\
(2011)\end{array}$ & $\begin{array}{l}\text { Carley (2009), } \\
\text { Marques et al. (2010; } \\
\text { 2011), Shrimali and } \\
\text { Kneifel (2011) }\end{array}$ \\
\hline Area & Land area size & 1000 ha & $\begin{array}{l}\text { Faostat } \\
(2011)\end{array}$ & $\begin{array}{l}\text { Marques et al. (2010; } \\
\text { 2011) }\end{array}$ \\
\hline $\begin{array}{l}\text { Net import } \\
\text { ratio }\end{array}$ & $\begin{array}{l}\text { Natural logarithm of net electricity } \\
\text { imported to total electricity produced }\end{array}$ & $\%$ & $\begin{array}{l}\text { Eurostat } \\
(2011)\end{array}$ & $\begin{array}{l}\text { Yin and Powers } \\
\text { (2009), Marques et } \\
\text { al. (2010; 2011) }\end{array}$ \\
\hline $\begin{array}{l}\text { Energy } \\
\text { consumptio } \\
\text { n per capita }\end{array}$ & $\begin{array}{l}\text { Natural logarithm of primary energy } \\
\text { consumption per capita }\end{array}$ & $\begin{array}{l}\text { MMBTU } \\
\text { per } \\
\text { capita }\end{array}$ & $\begin{array}{l}\text { U.S. EIA } \\
(2011), \\
\text { World Bank } \\
(2011)\end{array}$ & $\begin{array}{l}\text { Carley (2009), } \\
\text { Marques et al. (2010; } \\
\text { 2011) }\end{array}$ \\
\hline $\begin{array}{l}\text { EU } 2001 \\
\text { binary }\end{array}$ & $\begin{array}{l}\text { Indicates the ratification year of the } \\
2001 / E C / 77 \text { Directive }\end{array}$ & Binary & $\begin{array}{l}\text { European } \\
\text { Commission } \\
(2001)\end{array}$ & $\begin{array}{l}\text { Marques et al. (2010; } \\
\text { 2011) }\end{array}$ \\
\hline
\end{tabular}

Yin and Powers (2009) point out the importance of energy dependency as a driver of RES-E development. As global reserves of conventional energy sources decline and emerging economies rapidly increase their energy demand, incentivizing RES-E development represents an increasingly common strategy for Western countries to improve their energy independence. Therefore, we expect a positive link between a high share of net imported electricity and RES-E development. A similar rationale suggests that RES-E capacity will develop more rapidly in countries with high primary energy consumption. Marques (2010; 2011) find a significant positive connection between the per capita consumption of energy and the share of renewable energy relative to total energy supply. We include the same variable to verify the connection. 
Finally, EU 2001 is a time binary dummy differentiating the years before and after the European Commission first ratified a binding RES-E directive. ${ }^{4}$ The Directive 2001/EC/77 provides a legally enforceable commitment for the EU member states to implement RES-E support policies. Policy responses to the Directive have ranged from strong to negligible, but each member country has passed some RES-E legislation as a result. This variable captures any systematic changes in the responsiveness of RES-E development to drivers before and after the Directive was ratified.

\subsection{Model specification}

We assemble historical 1992-2008 panel data for the variables discussed above. We then analyze this data within a country-level fixed-effects regression model to assess the effect of FIT policies on wind and PV capacity development. As Shrimali and Kneifel (2011) note, fixed effects control for any country-level characteristics that remain constant over time-including potential for RES-E (e.g. solar insolation and windiness), land area, capacity construction before 1992, and time-invariant environmental preferences. $^{5}$ For energy technology $i$, in country $s$, in year $t$, our main regression model is:

(1) $\quad$ In Added Capacity $_{\text {ist }}=\beta_{0}+\beta_{1}$ ROI $_{\text {ist }}+\beta_{2} I N C R Q M T S H A R E_{\text {st }}$

$$
+\beta_{x} Z_{i s t}+\beta_{y} W_{i s t}+\mu_{s}+u_{i s t}
$$

where Added Capacity ${ }_{i s t}$ is the additional RES-E generation capacity installed between years $t-1$ and $t$ for energy technology $i$ (solar PV or onshore wind); $\mathrm{ROI}_{\text {ist }}$ is our technology-specific indicator for FIT strength; INCRQMTSHARE ${ }_{\text {st }}$ is the indicator for RPS strength developed in Yin and Powers (2009); $Z_{\text {ist }}$ is a suite of binary variables that represent other policies designed to encourage RES-E development; $W_{\text {ist }}$ is a suite of social and economic variables expected to have an impact on RES-E development; $\mu_{s}$ represents country-level fixed effects; and $\mathrm{u}_{\text {ist }}$ is an error term. In some regressions, we exchange ROI ${ }_{\text {ist }}$ for ROI_ $1_{\text {ist }}$ and ROI_ $0_{\text {ist }}$.

\footnotetext{
${ }^{4}$ For years after the ratification of the Directive, the binary code is "on" only if a country was an EU member at that time.

${ }^{5}$ A Hausman test rejects the hypothesis of no unit heterogeneity, confirming the need to control for unobserved differences between states.
} 
We first run preliminary regressions to establish the baseline relationship between added RES-E capacity and policy variables for both wind and PV. The first is a pooled crosssection regression that does not control for country-level fixed effects and the second is a fixed-effects regression that employs conventional binary policy variables only. We then run a series of regressions using the model given in Equation (1).

\section{Results}

Table 5 displays the results of our preliminary pooled cross-section regressions. These regressions reveal a large, positive, and highly significant relationship between FIT policies and RES-E development. This is observed across both technology types and both policy variables (binary and ROI). As shown in regressions (1) and (4), a country with a FIT in place will install $57 \%$ more PV capacity or $120 \%$ more onshore wind capacity per year than a country with no FIT. As shown in (2) and (5), a 10 percentage point increase in the ROI provided by a FIT policy is associated with an increase in annual capacity added of 8.1\% for PV and $7.1 \%$ for wind. ${ }^{6}$ However, the link between policy and capacity revealed by a pooled cross-section regression cannot be interpreted as causal because omitted variables (such as country characteristics) may bias the coefficients.

Table 6 presents the results from several estimations of our main regression model given in Equation (1). The specifications provided here are identical to those in Table 5 except that we now employ state-level fixed effects to control for unobserved state characteristics that are static over time. Across both technology types and all specifications, coefficients are universally lower when fixed effects are introduced.

\footnotetext{
${ }^{6}$ In other words, a one unit increase in the ROI indicator (i.e. an increase of 100 percentage points) would be associated with an increase in annual capacity added of $81 \%$ for PV and $71 \%$ for wind. However, we use a 10 percentage point increase in ROI for illustrative purposes because it is a more realistic example of ROI changes that may actually occur on a year to year basis.
} 
Table 5: Pooled cross-section OLS regression results

\begin{tabular}{|c|c|c|c|c|c|c|}
\hline & \multicolumn{3}{|c|}{ Solar Photovoltaic } & \multicolumn{3}{|c|}{ Onshore Wind } \\
\hline & (1) & (2) & (3) & (4) & (5) & (6) \\
\hline Binary FIT & $\begin{array}{l}0.566^{* * *} \\
(0.109)\end{array}$ & & & $\begin{array}{l}1.202^{* * *} \\
(0.188)\end{array}$ & & \\
\hline ROI & & $\begin{array}{l}0.810^{* * *} \\
(0.101)\end{array}$ & & & $\begin{array}{l}0.710^{* * *} \\
(0.163)\end{array}$ & \\
\hline ROI_1 & & & $\begin{array}{l}1.075^{* * *} \\
(0.147)\end{array}$ & & & $\begin{array}{l}0.414^{* *} \\
(0.186)\end{array}$ \\
\hline ROI_0 & & & $\begin{array}{l}0.286^{* * *} \\
(0.090)\end{array}$ & & & $\begin{array}{l}1.494^{* * *} \\
(0.226)\end{array}$ \\
\hline INCRMTSHARE & $\begin{array}{l}-2.873 \\
(2.768)\end{array}$ & $\begin{array}{l}0.540 \\
(2.150)\end{array}$ & $\begin{array}{l}0.437 \\
(2.190)\end{array}$ & $\begin{array}{l}14.663^{* * *} \\
(4.727)\end{array}$ & $\begin{array}{l}3.230 \\
(5.107)\end{array}$ & $\begin{array}{l}-2.841 \\
(5.714)\end{array}$ \\
\hline Binary Tax or Grant & $\begin{array}{l}-0.106 \\
(0.130)\end{array}$ & $\begin{array}{l}0.117 \\
(0.121)\end{array}$ & $\begin{array}{l}0.151 \\
(0.125)\end{array}$ & $\begin{array}{l}-0.010 \\
(0.278)\end{array}$ & $\begin{array}{l}-0.648^{* *} \\
(0.301)\end{array}$ & $\begin{array}{l}-0.709^{* *} \\
(0.286)\end{array}$ \\
\hline Binary Tendering Scheme & $\begin{array}{l}-0.422^{* * *} \\
(0.161)\end{array}$ & $\begin{array}{l}0.044 \\
(0.131)\end{array}$ & $\begin{array}{l}-0.006 \\
(0.135)\end{array}$ & $\begin{array}{l}0.404 \\
(0.283)\end{array}$ & $\begin{array}{l}0.133 \\
(0.283)\end{array}$ & $\begin{array}{l}0.358 \\
(0.278)\end{array}$ \\
\hline Binary EU 2001 & $\begin{array}{l}-0.110 \\
(0.261)\end{array}$ & $\begin{array}{l}0.068 \\
(0.216)\end{array}$ & $\begin{array}{l}0.106 \\
(0.204)\end{array}$ & $\begin{array}{l}0.083 \\
(0.376)\end{array}$ & $\begin{array}{l}0.262 \\
(0.367)\end{array}$ & $\begin{array}{l}0.175 \\
(0.355)\end{array}$ \\
\hline GDP p.C., In & $\begin{array}{l}0.672^{* * *} \\
(0.134)\end{array}$ & $\begin{array}{l}0.067 \\
(0.103)\end{array}$ & $\begin{array}{l}0.263^{* * *} \\
(0.093)\end{array}$ & $\begin{array}{l}2.351^{* * *} \\
(0.236)\end{array}$ & $\begin{array}{l}2.346^{* * *} \\
(0.237)\end{array}$ & $\begin{array}{l}2.068^{* * *} \\
(0.231)\end{array}$ \\
\hline Energy Consumption p.C., In & $\begin{array}{l}0.035 \\
(0.166)\end{array}$ & $\begin{array}{l}0.226 \\
(0.150)\end{array}$ & $\begin{array}{l}-0.027 \\
(0.149)\end{array}$ & $\begin{array}{l}-0.708^{* *} \\
(0.361)\end{array}$ & $\begin{array}{l}-0.228 \\
(0.364)\end{array}$ & $\begin{array}{l}0.016 \\
(0.368)\end{array}$ \\
\hline Area, In & $\begin{array}{l}0.339 * * * \\
(0.056)\end{array}$ & $\begin{array}{l}0.245^{* * *} \\
(0.043)\end{array}$ & $\begin{array}{l}0.213^{* * *} \\
(0.041)\end{array}$ & $\begin{array}{l}0.842^{* * *} \\
(0.079)\end{array}$ & $\begin{array}{l}0.943^{* * *} \\
(0.074)\end{array}$ & $\begin{array}{l}0.900^{* * *} \\
(0.075)\end{array}$ \\
\hline Energy Net Import Ratio, In & $\begin{array}{l}-0.054^{* * *} \\
(0.020)\end{array}$ & $\begin{array}{l}0.004 \\
(0.015)\end{array}$ & $\begin{array}{l}0.016 \\
(0.014)\end{array}$ & $\begin{array}{l}-0.011 \\
(0.029)\end{array}$ & $\begin{array}{l}-0.044 \\
(0.029)\end{array}$ & $\begin{array}{l}-0.027 \\
(0.029)\end{array}$ \\
\hline Share of Elec. from Nuclear, In & $\begin{array}{l}0.049 * \\
(0.025)\end{array}$ & $\begin{array}{l}0.038^{*} \\
(0.021)\end{array}$ & $\begin{array}{l}0.034 \\
(0.021)\end{array}$ & $\begin{array}{l}-0.017 \\
(0.044)\end{array}$ & $\begin{array}{l}-0.057 \\
(0.044)\end{array}$ & $\begin{array}{l}-0.042 \\
(0.042)\end{array}$ \\
\hline Share of Elec. from Oil, In & $\begin{array}{l}0.019 \\
(0.045)\end{array}$ & $\begin{array}{l}0.066 \\
(0.041)\end{array}$ & $\begin{array}{l}0.039 \\
(0.040)\end{array}$ & $\begin{array}{l}0.146^{*} \\
(0.084)\end{array}$ & $\begin{array}{l}0.264 * * * \\
(0.087)\end{array}$ & $\begin{array}{l}0.303^{* * *} \\
(0.088)\end{array}$ \\
\hline Share of Elec. from Nat. Gas, In & $\begin{array}{l}0.132 * * * \\
(0.039)\end{array}$ & $\begin{array}{l}0.131^{* * * *} \\
(0.033)\end{array}$ & $\begin{array}{l}0.147^{* * *} \\
(0.031)\end{array}$ & $\begin{array}{l}0.356^{* * * *} \\
(0.067)\end{array}$ & $\begin{array}{l}0.315^{* * *} \\
(0.064)\end{array}$ & $\begin{array}{l}0.285^{* * *} \\
(0.064)\end{array}$ \\
\hline Share of Elec. from Coal, In & $\begin{array}{l}0.017 \\
(0.029)\end{array}$ & $\begin{array}{l}0.007 \\
(0.025)\end{array}$ & $\begin{array}{l}0.016 \\
(0.024)\end{array}$ & $\begin{array}{l}0.202^{* * *} \\
(0.053)\end{array}$ & $\begin{array}{l}0.210^{* * *} \\
(0.054)\end{array}$ & $\begin{array}{l}0.223^{* * *} \\
(0.056)\end{array}$ \\
\hline $\mathrm{N}$ & 440 & 440 & 440 & 440 & 440 & 440 \\
\hline R2 & 0.309 & 0.503 & 0.536 & 0.614 & 0.611 & 0.625 \\
\hline
\end{tabular}

Standard errors in parentheses. The dependent variable is the natural log of annual solar PV or onshore wind capacity added (in MW). * Significant at 10\%, ** Significant at 5\%, *** Significant at $1 \%$. 
Table 6: Fixed effects regression results

\begin{tabular}{|c|c|c|c|c|c|c|}
\hline & \multicolumn{2}{|c|}{ Solar Photovoltaic } & \multicolumn{3}{|c|}{ Onshore Wind } & \multirow[b]{2}{*}{ (6) } \\
\hline & (1) & (2) & (3) & (4) & (5) & \\
\hline Binary FIT & $\begin{array}{l}0.054 \\
(0.136)\end{array}$ & & & $\begin{array}{l}0.486^{* *} \\
(0.199)\end{array}$ & & \\
\hline ROI & & $\begin{array}{l}0.592^{* * *} \\
(0.082)\end{array}$ & & & $\begin{array}{l}0.436^{* * *} \\
(0.121)\end{array}$ & \\
\hline ROI_1 & & & $\begin{array}{l}0.818^{* * *} \\
(0.097)\end{array}$ & & & $\begin{array}{l}0.221^{*} \\
(0.129)\end{array}$ \\
\hline ROI_0 & & & $\begin{array}{l}0.119 \\
(0.139) \\
\end{array}$ & & & $\begin{array}{l}1.278^{* * *} \\
(0.231)\end{array}$ \\
\hline INCRMTSHARE & $\begin{array}{l}4.910 \\
(4.100)\end{array}$ & $\begin{array}{l}4.317 \\
(3.839)\end{array}$ & $\begin{array}{l}3.120 \\
(3.774)\end{array}$ & $\begin{array}{l}7.008 \\
(6.094)\end{array}$ & $\begin{array}{l}4.405 \\
(5.996)\end{array}$ & $\begin{array}{l}-2.294 \\
(6.080)\end{array}$ \\
\hline Binary Tax or Grant & $\begin{array}{l}0.194 \\
(0.224)\end{array}$ & $\begin{array}{l}0.190 \\
(0.211)\end{array}$ & $\begin{array}{l}0.195 \\
(0.207)\end{array}$ & $\begin{array}{l}0.646^{*} \\
(0.332)\end{array}$ & $\begin{array}{l}0.404 \\
(0.336)\end{array}$ & $\begin{array}{l}0.303 \\
(0.330)\end{array}$ \\
\hline Binary Tendering Scheme & $\begin{array}{l}-0.002 \\
(0.202)\end{array}$ & $\begin{array}{l}-0.021 \\
(0.190)\end{array}$ & $\begin{array}{l}-0.060 \\
(0.186)\end{array}$ & $\begin{array}{l}-0.380 \\
(0.299)\end{array}$ & $\begin{array}{l}-0.409 \\
(0.296)\end{array}$ & $\begin{array}{l}-0.355 \\
(0.290)\end{array}$ \\
\hline Binary EU 2001 & $\begin{array}{l}-0.137 \\
(0.212)\end{array}$ & $\begin{array}{l}0.055 \\
(0.201)\end{array}$ & $\begin{array}{l}0.085 \\
(0.197)\end{array}$ & $\begin{array}{l}0.002 \\
(0.314)\end{array}$ & $\begin{array}{l}0.113 \\
(0.314)\end{array}$ & $\begin{array}{l}0.075 \\
(0.307)\end{array}$ \\
\hline GDP p.C., In & $\begin{array}{l}-0.567 \\
(0.424)\end{array}$ & $\begin{array}{l}-0.879^{* *} \\
(0.390)\end{array}$ & $\begin{array}{l}-0.268 \\
(0.409)\end{array}$ & $\begin{array}{l}1.640^{* * *} \\
(0.634)\end{array}$ & $\begin{array}{l}1.084 \\
(0.664)\end{array}$ & $\begin{array}{l}0.357 \\
(0.672)\end{array}$ \\
\hline Energy Consumption p.C., In & $\begin{array}{l}1.139 * \\
(0.693)\end{array}$ & $\begin{array}{l}0.568 \\
(0.652)\end{array}$ & $\begin{array}{l}0.610 \\
(0.640)\end{array}$ & $\begin{array}{l}1.486 \\
(1.024)\end{array}$ & $\begin{array}{l}1.820^{*} \\
(1.011)\end{array}$ & $\begin{array}{l}1.714^{*} \\
(0.990)\end{array}$ \\
\hline Energy Net Import Ratio, In & $\begin{array}{l}0.031 \\
(0.040)\end{array}$ & $\begin{array}{l}-0.008 \\
(0.038)\end{array}$ & $\begin{array}{l}0.003 \\
(0.037)\end{array}$ & $\begin{array}{l}0.116^{*} \\
(0.060)\end{array}$ & $\begin{array}{l}0.077 \\
(0.061)\end{array}$ & $\begin{array}{l}0.086 \\
(0.060)\end{array}$ \\
\hline Share of Elec. from Nuclear, In & $\begin{array}{l}-0.234 \\
(0.193)\end{array}$ & $\begin{array}{l}-0.334^{*} \\
(0.182)\end{array}$ & $\begin{array}{l}-0.361^{* *} \\
(0.179)\end{array}$ & $\begin{array}{l}0.082 \\
(0.287)\end{array}$ & $\begin{array}{l}0.088 \\
(0.284)\end{array}$ & $\begin{array}{l}0.065 \\
(0.278)\end{array}$ \\
\hline Share of Elec. from Oil, In & $\begin{array}{l}-0.285^{* *} \\
(0.133)\end{array}$ & $\begin{array}{l}-0.170 \\
(0.125)\end{array}$ & $\begin{array}{l}-0.190 \\
(0.123)\end{array}$ & $\begin{array}{l}0.057 \\
(0.196)\end{array}$ & $\begin{array}{l}0.190 \\
(0.198)\end{array}$ & $\begin{array}{l}0.265 \\
(0.195)\end{array}$ \\
\hline Share of Elec. from Nat. Gas, In & $\begin{array}{l}0.445^{* * *} \\
(0.111)\end{array}$ & $\begin{array}{l}0.264^{* *} \\
(0.107)\end{array}$ & $\begin{array}{l}0.197^{*} \\
(0.106)\end{array}$ & $\begin{array}{l}1.116^{* * *} \\
(0.164)\end{array}$ & $\begin{array}{l}1.136^{* * *} \\
(0.163)\end{array}$ & $\begin{array}{l}1.151^{* * *} \\
(0.159)\end{array}$ \\
\hline Share of Elec. from Coal, In & $\begin{array}{l}-0.338 \\
(0.252)\end{array}$ & $\begin{array}{l}-0.417^{*} \\
(0.237)\end{array}$ & $\begin{array}{l}-0.377 \\
(0.232)\end{array}$ & $\begin{array}{l}0.205 \\
(0.373)\end{array}$ & $\begin{array}{l}0.338 \\
(0.372)\end{array}$ & $\begin{array}{l}0.323 \\
(0.364)\end{array}$ \\
\hline $\mathrm{N}$ & 440 & 440 & 440 & 440 & 440 & 440 \\
\hline R2 & 0.153 & 0.251 & 0.282 & 0.381 & 0.392 & 0.418 \\
\hline
\end{tabular}

Standard errors in parentheses. The dependent variable is the natural log of annual solar PV or onshore wind capacity added (in MW). * Significant at 10\%, ** Significant at 5\%, *** Significant at $1 \%$.

However, the fixed-effects regression results indicate that feed-in tariffs have driven solar PV and onshore wind development in Europe since 1992, even when fixed country characteristics are controlled. Specifically, regressions (2) and (5) of Table 6 indicate that for a 10 percentage point increase in ROI, countries will install $5.9 \%$ more PV capacity and $4.3 \%$ more onshore wind capacity per year on average. Regressions (3) and (6) confirm that ROI is a significant driver of capacity development in country-years with a FIT. However, in country-years without a FIT, ROI appears to drive development of wind power but not PV.

Both the magnitude and significance of coefficients vary dramatically between regressions (1) and (2) and slightly between regressions (4) and (5), implying that policy design features are an important control. In the case of PV, the FIT coefficient is much smaller and insignificant when a simple binary policy variable is used in (1). This suggests that there is a genuine relationship 
between policy and solar PV development that is masked without taking into account the unique design of each FIT.

Several control variables in the fixed-effects regression are significant determinants of RES-E capacity development as well. However, only the coefficient on share of electricity from natural gas remains positive and significant throughout the six regressions. These results are discussed in more detail in the following section.

\section{Discussion}

\subsection{Interpretation of findings}

The results of this analysis confirm the general conclusion in the literature that feed-in tariffs have driven RES-E capacity development in Europe, especially for solar PV. A key question for policymakers is whether FIT policies increase RES-E development beyond the rate at which it would have developed otherwise. In other words, do the policies have a marginal impact on capacity, or do countries incur public expense to subsidize only inframarginal development that would have happened anyway? Our panel-driven fixed-effects approach verifies that FIT policies have contributed some marginal impact by providing a true production incentive, though the results are not sufficient to make claims about the portion of each tariff that provides marginal vs. inframarginal incentive.

Our results also reinforce the importance of incorporating information about unique policy design elements into econometric analysis of RES-E policies. Including a statistical representation of return on investment into our regressions, rather than relying on traditional binary policy variables, produces dramatically different results. In the case of solar PV, the link between FIT policies and RES-E development is insignificant when using a binary indicator and significant at less than $1 \%$ when using ROI. The implication of this result is that specific policy design and market characteristics matter more than the presence of a policy alone in determining RES-E development. In other words, not all feed-in tariffs are created equal, and policy design matters. FIT policies do not increase solar PV capacity development simply by virtue of being enacted, but it can be shown that the higher true ROI they provide to investors, the more capacity will be installed on average. This insight is informative in a world of political discourse that is often more focused on the morality of a policy type than on the intricacies of its specific design.

Comparing ROI_1 and ROI_0 in regression (3) confirms a common theme in energy policy debates in Europe: without a FIT, solar PV development would not be driven by the return on 
investment provided by the market alone. This regression provides an important robustness check to ensure that the coefficient on ROI in regression (2) is not driven only or primarily by ROI in country-years where no FIT is in place. When a FIT is introduced, the impact of a 10 percentage point increase in ROI jumps from an insignificant 1.2\% (ROI_0) to an 8.2\% (ROI_1) that is significant at the $1 \%$ level. Note that this does not necessarily imply that a low ROI prevented PV development; it implies that there is no statistically significant link between development and market ROI at all. This may be because, in country-years with no FIT, ROI for $\mathrm{PV}$ is low and therefore deployment is driven by other factors such as culture or environmental concerns (most of which will be controlled by fixed effects). In country-years with a FIT, ROI alone is a large enough decision-making factor for investors that it provides incentive for PV deployment beyond that provided by these other factors.

These results change when we turn to onshore wind. Because wind is a more mature technology with lower generation costs than solar PV, ROI provides a strong incentive for wind development even in country-years without policy support. Regression (6) shows that a 10 percentage point increase in ROI_0 would increase installed wind capacity by $12.8 \%$ per year. In other words, investment returns are a significant decision-making factor for investors even without the support of a FIT. The relationship between policy and development in country-years with a FIT is positive and significant, but it is curiously about six times smaller in magnitude than in country-years with no FIT. This may imply that FIT policies for wind are largely redundant-i.e. that the additional ROI they provide is not a large determinant of wind power development. However, this may also be due to the statistical limitations of the ROI_1 and ROI_0 indicators. For about half of the countries in our sample, annual wind capacity installations peaked and then declined (sometimes dramatically) in the years leading up to 2008. During those years, most countries also had some form of FIT for wind, so the FIT_0 indicator was forced to take the value 0 while ROI_1 remained high. This may have led to an overestimation of the coefficient on ROI_0 and an underestimation of that on ROI_1. A more sophisticated effort to parse out policy-driven $\mathrm{ROI}$ from market ROI may be required to resolve this issue. For now, the results in regressions (4)-(6) appear sufficient to confirm at least some link between FIT policies and wind development.

Our analysis of FIT policies follows a pattern similar to that of the three groups of RPS literature discussed in Section 2. Like the first group, we see a large, positive, and highly significant link between policy and development when using a pooled cross-section model. However, this effect can be both intuitively assumed and statistically shown to be overstated because it is biased by unobserved country characteristics that influence both policy and 
development. When we include controls for fixed effects per the second group of studies, this apparent link is dramatically reduced (for wind) or becomes statistically insignificant (for PV). Finally, when we employ a more nuanced indicator that reflects the true incentive provided by a FIT-as Yin and Powers (2009) did for RPS in the U.S. - we reestablish a link between policy and development. We hope that these results will motivate careful consideration of controls and policy design in future RES-E policy analysis.

Our analysis does not provide robust evidence that non-FIT RES-E policies have increased capacity development. This verifies the findings from Masini and Menichetti (2010) and other survey-based studies that we discussed in subsection 3.2.

Other than the share of electricity from natural gas, most of our economic control variables were not shown to be significant determinants of RES-E development. Natural gas share appears to have a significant positive impact on both wind and PV capacity development in all our OLS and fixed-effect regressions. The "Golden Age of Gas" (IEA 2011b) seems to be partly driven by the ability of natural gas plants to balance the intermittency of RES-E generation sources that are subject to day/night cycles and weather. Electricity generation from burning natural gas is roughly half as carbon dioxide intensive as the equivalent in coal-fired generation, and it performs even better with Nitrogen, Sulfur and Mercury emissions. With these benefits, natural gas is an attractive candidate to supplement RES-E generation for both logistical and environmental reaaons.

Our results do not confirm Yin and Powers (2009) finding that the ratio of net imports of electricity to domestically produced electricity is a significant and positive driver of RES-E development. They also do not confirm the assertion by Marques et al. that there is a slight underlying influence of per capita energy consumption on RES-E development. Because our fixed-effects model drops variables that are constant over time, we could not verify the significant, positive effect of land area on RES-E deployment that was demonstrated by the FEVD model in Marques et al. (2010). However, our pooled cross-section regressions do indicate a strong relationship between land area and RES-E development.

\subsection{A more nuanced ROI indicator}

The ROI indicator we employed for our empirical investigation is a fine-grained metric to assess the real strength of a FIT. In fact, it reveals a link between FIT policies and RES-E development that would have been masked using a traditional binary policy variable. ROI does not incorporate all relevant variables that help determine the investment incentive 
created by a FIT, but it can serve as a stepping-stone to develop a more informative and comprehensive theoretical indicator that incorporates factors we cannot currently measure empirically.

Stimulating investment with FIT policies is a complex matter, and it is important to understand that some additional factors contribute to the uniqueness of each policy and the market it affects. Investment is not done in a social and economic vacuum under perfect market conditions, but in a dynamic environment of uncertainties and bounded rationality of its actors (Simon 1957). Investment decisions are embedded in a socioeconomic reality that is shaped by interactions and dynamics we cannot quantify at this point. What we can do, however, is to further elaborate on our ROI indicator and use it as a theoretical tool to better understand some of these more amorphous factors.

This expanded indicator, which we will call ROI_U because it incorporates elements of uncertainty, may take the following form, for energy technology $i$, in country $s$, in year $t$ :

$\mathrm{ROI}_{-} \mathrm{U}_{\mathrm{ist}}=\frac{\mathrm{FIT}_{\mathrm{ist}} * \mathrm{CT}_{\mathrm{ist}} * \phi_{i s t}+\mathrm{P}_{\mathrm{st}} * \mathrm{LT}_{\mathrm{it}}-\mathrm{CT}_{\mathrm{ist}} * \mu_{s t} * \Delta_{s t}-\mathrm{ACOE}_{\mathrm{ist}} * \mathrm{LT}_{\mathrm{i}, \mathrm{t}} * \varphi_{i s t}}{\mathrm{ACOE}_{\mathrm{ist}} * \mathrm{LT}_{\mathrm{it}} * \varphi_{i s t}}$

As discussed in Masini and Menichetti (2010), there are three sources of ex-ante uncertainty that may influence investment decisions.

The first has to do with technology. Risk concerning RES-E technology's current efficiency and future cost development will impact the investment choice as well as the timing of investment. To account for technological uncertainty, we expand ROI by incorporating the purely theoretical parameter $\varphi$. It primarily affects fixed upfront costs faced by RES-E investors. As has been pointed out by Nemet (2006) and others, technologies become more cost-efficient over time. Since successful innovations have a heavily left-tailed distribution and are hard to predict, investors will experience additional uncertainty in making long-term investments in high-technology products. Therefore, we assume $\varphi$ has a positive impact on expected future costs which yields a negative impact on current investment incentive, such that $\operatorname{ROI}_{-} U_{\text {ist }}{ }^{\prime} \varphi<0$. The 
conservative investor may shift investment to the future if he expects a divergence caused by costs decreasing faster than the tariff digresses $(\varphi>$ digression rate). If policymakers seem more likely to reduce or eliminate tariffs in the future, investment in the present will look more attractive.

The second involves uncertainty surrounding the market at large. In ROI_U, we represent spot market uncertainty with $\mu$. Premium tariffs are paid as a bonus to the spot market price, and RES-E producers will received the market price for any electricity generated after a tariff contract has expired. Therefore, the expected return on investment largely depends on this price. Since fluctuations are inevitable and the general trend of price development is unclear even (or especially) to researchers, investors add another element of uncertainty to their calculus. Since uncertainty decreases attractiveness in the long-run, we assume $R O I_{-} U_{i s t}{ }^{\prime} \mu<0$ for risk-averse investors. Price uncertainty decreases ROI_U to a greater degree when it is combined with short contract durations, as the capacity will be operating for more of its lifetime without the added benefit of a tariff and will be more reliant on market price for revenue. The years that occur during the capacity's lifetime (LT) but after the contract duration (CT) has ended will add vulnerability of $(L T-C T) * \mu$ for the investor.

The political environment is a third source of uncertainty for the investor. In ROI_U, $\phi$ represents the degree of political uncertainty surrounding the FIT policy. We expect $R O I_{-} U_{i s t}{ }^{\prime} \phi<0$, which means that an increase in political instability or a loss of political reliability adds doubt to the expected return on investment of RES-E capacity. If a FIT can be repealed or revised, investors are more reluctant to direct capital into projects that rely on the FIT for good returns. In most cases, the contractor is legally entitled to receive a fixed tariff. However, the example of Spain shows that legislators may violate this long-term commitment in times of short-term economic turmoil, thus putting the expected return on investment at risk.

Finally, the term $\Delta$ represents the portion of the electricity price that is added because the FIT redistributes money between end-users in order to finance the FIT. In some cases, the price of the tariff is allocated to end-users by increasing the price of electricity generated from conventional sources. The more heavily RES-E is subsidized by a FIT, the more money is added to the pre-FIT market price, which in turn leads to an 
increase in ROI_U, such that $R_{0} I_{-} U_{\text {ist }}{ }^{\prime}(\Delta)>0$. In other words, the FIT can be a selfreinforcing mechanism to promote RES-E while the end-users or the state budget bear the cost.

The elements of uncertainty included in ROI_U are difficult to represent empirically. However, there may be opportunities to use proxy data, survey results, or other strategies to characterize them in future studies. In the meantime, ROI_U serves as a useful theoretical tool for thinking about how future uncertainty and risk affect RES-E investment decisions today.

\subsection{Conclusion}

This paper provides the first rigorous econometric analysis of feed-in tariff policy effectiveness in Europe. Previous analyses of RES-E policies in general have often taken a blunt approach, using cross-sectional models or ignoring differences in policy design.

In this paper, we employ a fixed-effects regression model to control for countrylevel characteristics. We also introduce a new measure of policy strength that represents the return on investment provided by feed-in tariffs. We find that FIT policies have driven solar photovoltaic and onshore wind power capacity development in Europe since 1992. We verify that fixed country-level characteristics will bias the results if not controlled, and we show that accounting for the unique design of each FIT often reveals a link between policy and RES-E development that is otherwise obscured.

These results imply that the design of each policy and the market it affects are more important determinants of RES-E development than the enactment of a policy alone. This should prove informative to both researchers and policymakers. In future analyses, we hope to (1) more rigorously characterize the uncertainty surrounding policy and market conditions and (2) analyze the relative impact of each policy design element on RES-E development. This may provide insight into strategies for optimizing FIT performance. 


\section{Appendices}

Table A1: Summary Statistics

\begin{tabular}{llllll}
\hline \hline Variable & Obs & Mean & Std. Dev. & Min & Max \\
\hline Added Capacity PV & 442 & 21.52 & 170.03 & -38.00 & 2586.00 \\
Added Capacity Wind & 442 & 144.04 & 426.54 & -352.00 & 3247.00 \\
\hline ROI, PV & 442 & -0.35 & 0.92 & -0.96 & 2.93 \\
ROI_1, PV & 442 & 0.19 & 0.65 & -0.96 & 2.93 \\
ROI_0, PV & 442 & -0.55 & 0.45 & -0.96 & 0.78 \\
ROI, Wind & 442 & -0.07 & 0.81 & -0.80 & 4.85 \\
ROI_1, Wind & 442 & 0.21 & 0.61 & -0.80 & 4.85 \\
ROI_0, Wind & 442 & -0.28 & 0.41 & -0.80 & 1.53 \\
INCRMTSHARE & 442 & 0.00 & 0.01 & -0.02 & 0.14 \\
Binary Tax or Grant & 442 & 0.10 & 0.29 & 0 & 1 \\
Binary Tendering Scheme & 442 & 0.11 & 0.31 & 0 & 1 \\
Binary EU 2001 & 442 & 0.04 & 0.19 & 0 & 1 \\
GDP p.C. & 442 & 22889.20 & 11422.75 & 5867.64 & 74421.63 \\
Energy Consumption p.C. & 440 & 159.59 & 68.40 & 61.92 & 432.58 \\
Area & 442 & 16080.04 & 15560.07 & 259.00 & 54766.00 \\
Energy Net Import Ratio & 442 & -14.90 & 75.74 & -737.75 & 69.16 \\
Share of Electricity from Nuclear & 442 & 21.84 & 24.59 & 0 & 86.82 \\
Share of Electricity from Oil & 442 & 9.80 & 19.98 & 0 & 100 \\
Share of Electricity from Natural Gas & 442 & 17.45 & 17.25 & 0 & 76.33 \\
Share of Electricity from Coal & 442 & 31.62 & 26.98 & 0 & 95.37 \\
\hline \hline
\end{tabular}


Table A2: Correlation Matrix

\begin{tabular}{|c|c|c|c|c|c|c|c|}
\hline & $\begin{array}{l}\text { Tax/ } \\
\text { Grant }\end{array}$ & Tender & ROI, pv & ROI, wind & ROI_1,PV & ROI_0, PV & $\begin{array}{l}\text { ROI_1, } \\
\text { Wind }\end{array}$ \\
\hline Binary for Tax or Grant & 1.00 & & & & & & \\
\hline Binary for Tendering Scheme & 0.18 & 1.00 & & & & & \\
\hline ROI, pv & -0.11 & -0.14 & 1.00 & & & & \\
\hline ROI, wind & 0.25 & -0.01 & 0.53 & 1.00 & & & \\
\hline ROI_1, PV & -0.12 & -0.10 & 0.89 & 0.28 & 1.00 & & \\
\hline ROI_0, PV & -0.06 & -0.13 & 0.75 & 0.67 & 0.36 & 1.00 & \\
\hline ROI_1, Wind & 0.22 & 0.05 & 0.35 & 0.87 & 0.21 & 0.41 & 1.00 \\
\hline ROI_0, Wind & 0.15 & -0.10 & 0.52 & 0.68 & 0.23 & 0.72 & 0.23 \\
\hline INCRMTSHARE & -0.03 & -0.05 & -0.03 & 0.09 & -0.02 & -0.04 & -0.05 \\
\hline Binary EU 2001 & 0.02 & 0.08 & 0.00 & -0.04 & -0.02 & 0.03 & -0.07 \\
\hline GDP p.C., ln & 0.10 & 0.24 & 0.43 & 0.32 & 0.33 & 0.40 & 0.18 \\
\hline Energy Consumption pC., ln & 0.16 & 0.23 & 0.24 & 0.15 & 0.22 & 0.17 & 0.10 \\
\hline Area, $\ln$ & 0.02 & 0.10 & 0.02 & -0.08 & 0.06 & -0.05 & -0.13 \\
\hline Energy Net Import Ratio, ln & 0.01 & -0.09 & -0.20 & -0.02 & -0.22 & -0.10 & 0.03 \\
\hline Share of Electricity from Nuclear, ln & 0.01 & 0.03 & -0.04 & -0.01 & 0.04 & -0.13 & 0.03 \\
\hline Share of Electricity from Oil, ln & -0.15 & 0.00 & -0.15 & -0.24 & -0.15 & -0.09 & -0.17 \\
\hline Share of Electricity from Nat. Gas, ln & 0.06 & 0.16 & 0.19 & 0.24 & 0.11 & 0.23 & 0.15 \\
\hline \multirow[t]{2}{*}{ Share of Electricity from Coal, ln } & 0.08 & 0.01 & 0.02 & 0.03 & 0.00 & 0.03 & 0.05 \\
\hline & $\begin{array}{l}\text { ROI_0, } \\
\text { Wind }\end{array}$ & $\begin{array}{l}\text { INCRMT- } \\
\text { SHARE }\end{array}$ & EU 2001 & $\begin{array}{l}\text { GDP p.C., } \\
\ln \end{array}$ & $\begin{array}{l}\text { Energy } \\
\text { Cons. p.C., } \\
\text { ln }\end{array}$ & Area, ln & $\begin{array}{l}\text { Net Imp. } \\
\text { R., ln }\end{array}$ \\
\hline ROI_0, Wind & 1.00 & & & & & & \\
\hline INCRMTSHARE & 0.26 & 1.00 & & & & & \\
\hline Binary EU 2001 & 0.03 & -0.04 & 1.00 & & & & \\
\hline GDP p.C., ln & 0.36 & 0.09 & 0.11 & 1.00 & & & \\
\hline Energy Consumption pC., ln & 0.14 & 0.09 & 0.08 & 0.78 & 1.00 & & \\
\hline Area, ln & 0.04 & 0.18 & 0.03 & -0.16 & -0.26 & 1.00 & \\
\hline Energy Net Import Ratio, ln & -0.09 & 0.09 & 0.01 & -0.05 & -0.09 & 0.27 & 1.00 \\
\hline Share of Electricity from Nuclear, ln & -0.07 & 0.10 & 0.00 & -0.10 & 0.16 & 0.31 & 0.05 \\
\hline Share of Electricity from Oil, ln & -0.21 & -0.10 & 0.00 & -0.13 & -0.42 & -0.03 & 0.26 \\
\hline Share of Electricity from Nat. Gas, ln & 0.26 & -0.12 & 0.07 & 0.29 & 0.17 & -0.07 & -0.15 \\
\hline \multirow[t]{2}{*}{ Share of Electricity from Coal, ln } & -0.02 & -0.14 & 0.01 & -0.18 & -0.19 & 0.35 & 0.07 \\
\hline & $\begin{array}{l}\text { Nuclear } \\
\text { Share, In }\end{array}$ & $\begin{array}{l}\text { Oil Share, } \\
\ln \end{array}$ & $\begin{array}{l}\text { Natural } \\
\text { Gas Share, } \\
\text { ln }\end{array}$ & $\begin{array}{l}\text { Coal } \\
\text { Share, ln }\end{array}$ & & & \\
\hline Share of Electricity from Nuclear, ln & 1.00 & & & & & & \\
\hline Share of Electricity from Oil, ln & -0.39 & 1.00 & & & & & \\
\hline Share of Electricity from Nat. Gas, In & -0.17 & -0.14 & 1.00 & & & & \\
\hline Share of Electricity from Coal, ln & -0.02 & -0.14 & 0.05 & 1.00 & & & \\
\hline
\end{tabular}




\section{References}

Adelaja, S. \& Hailu, Y. G. (2008), 'Effects of Renewable Portfolio Standards and Other State Policies on Wind Industry Development in the U.S.', Michigan State University, East Lansing, MI.

Alagappan, L.; Orans, R. \& Woo, C. (2011), 'What drives renewable energy development?', Energy Policy 39(9), 5099 - 5104.

Burer, M.J. \& Wustenhagen, R. (2009), 'Which renewable energy policy is a venture capitalist's best friend? Empirical evidence from a survey of international cleantech investors', Energy Policy 37, 4997-5006.

Carley, S. (2009), 'State renewable energy electricity policies: An empirical evaluation of effectiveness', Energy Policy 38(8), 3071 - 3081.

Couture, T. \& Gagnon, Y. (2010), 'An analysis of feed-in tariff remuneration models: Implications for renewable energy investment', Energy Policy 38(2), 955 - 965.

del Río González, P. \& Gual, M. A. (2007), 'An integrated assessment of the feed-in tariff system in Spain', Energy Policy 35(2), 994 - 1012.

del Río González, P. (2008), 'Ten years of renewable electricity policies in Spain: An analysis of successive feed-in tariff reforms', Energy Policy 36(8), 2917 - 2929.

Delmas, M. A. \& Montes-Sancho, M. J. (2011), 'U.S. state policies for renewable energy: Context and effectiveness', Energy Policy 39(5), 2273 - 2288.

DSIRE (2011), 'Database of State Incentives for Renewables and Efficiency', North Carolina Solar Center and the Interstate Renewable Energy Council, Raleigh, NC.

EEG (2009), 'Green-X. Deriving optimal promotion strategies for increasing the share of RES-E in a dynamic European electricity market', Energy Economics Group of the Vienna University of Technology, Vienna.

EEG (2009), 'Green-X Software. Deriving optimal promotion strategies for increasing the share of RES-E in a dynamic European electricity market', Energy Economics Group of the Vienna University of Technology, Vienna.

European Commission (2008), '20 20 by 2020. Europe's climate change opportunity'(COM/2008/0030 final), European Commission, Brussels.

European Parliament (2009), 'Directive 2009/28/EC of the European Parliament and of the Council of 23 April 2009 on the promotion of the use of energy from renewable sources and amending and subsequently repealing Directives 2001/77/EC and 2003/30/EC', Official Journal of the European Union 140, 16 - 62.

European Parliament (2001), 'Directive 2001/77/EC of the European Parliament and of the Council of 27 September 2001 on the promotion of electricity produced from renewable energy sources in the internal electricity market', Official Journal of the European Communities 283, 30 - 33.

Eurostat (2011), 'Statistics Database', European Commission, Luxembourg.

Food \& Agriculture Organization of the United Nations (2011), 'FAOStat. ResourceStat', Food and Agriculture Organization of the United Nations, Rome. 
Haas, R.; Eichhammer, W.; Huber, C.; Langniss, O.; Lorenzoni, A.; Madlener, R.; Menanteau, P.; Morthorst, P. E.; Martins, A.; Oniszk, A.; Schleich, J.; Smith, A.; Vass, Z. \& Verbruggen, A. (2004), 'How to promote renewable energy systems successfully and effectively', Energy Policy 32(6), 833 - 839.

Haas, R.; Meyer, N. I.; Held, A.; Finon, D.; Lorenzoni, A.; Wiser, R. \& Nishio, K.-I. (2008), Promoting Electricity from Renewable Energy Sources - Lessons Learned from the EU, United States, and Japan, in Fereidoon P. Sioshansi, ed., 'Competitive Electricity Markets', Elsevier, Oxford.

Haas, R.; Ragwitz, M.; Resch, G.; Panzer, C.; Busch, S. \& Held, A. (2011), 'Efficiency and effectiveness of promotion systems for electricity generation from renewable energy sources - Lessons from EU countries', Energy 36(4), 2186 - 2193.

Held, A.; Ragwitz, M. \& Haas, R. (2009), 'On the success of policy strategies for the promotion of electricity from renewable energy sources in the EU', Energy \& Environment 17(6), 849 - 868.

International Energy Agency (2011a), 'Policies and Measures Database', OECD/IEA, Paris. International Energy Agency (2011b), World Energy Outlook 2011. Special Report. Are we entering a Golden Age of Gas?, OECD/IEA, Paris.

Lesser, J. A. \& Su, X. (2008), 'Design of an economically efficient feed-in tariff structure for renewable energy development', Energy Policy 36(3), 981 - 990.

Lipp, J. (2007), 'Lessons for effective renewable electricity policy from Denmark, Germany and the United Kingdom', Energy Policy 35(11), 5481 - 5495.

Marques, A.; Fuinhas, J. \& Manso, J. (2011), 'A Quantile Approach to Identify Factors Promoting Renewable Energy in European Countries', Environmental \& Resource Economics 49(3), 351 - 366.

Marques, A. C.; Fuinhas, J. A. \& Pires Manso, J. (2010), 'Motivations driving renewable energy in European countries. A panel data approach', Energy Policy 38(11), 6877 - 6885.

Masini, A. \& Menichetti, E. (2010), 'The impact of behavioural factors in the renewable energy investment decision making process: Conceptual framework and empirical findings', Energy Policy (In press).

Menanteau, P.; Finon, D. \& Lamy, M.-L. (2003), 'Prices versus quantities. Choosing policies for promoting the development of renewable energy', Energy Policy 31(8), 799 812.

Menz, F. C. \& Vachon, S. (2006), 'The effectiveness of different policy regimes for promoting wind power: Experiences from the states', Energy Policy 34(14), 1786 - 1796.

Moreales, A. \& Sills, B. (2011), 'Impax, Hudson Clean Energy join investors suing Spain on solar subsidy cut', Bloomberg, Mar 8, 2011.

Nemet, G. F. (2006), 'Beyond the learning curve: factors influencing cost reductions in photovoltaics', Energy Policy 34(17), 3218 - 3232.

Palmer, K.; Paul, A.; Woerman, M. \& Steinberg, D. C. (2011), 'Federal policies for renewable electricity: Impacts and interactions', Energy Policy 39(7), 3975 - 3991. 
Ragwitz, M.; Rathmann, M.; Winkel, T.; Steinhilber, S.; Resch, G.; Panzer, C.; Busch, S. \& Konstantinaviciute, I. (2011), 'Renewable Energy Policy Country Profiles. 2011 Version', ECOFYS, Fraunhofer ISI, Energy Economics Group, Lithuanian Energy Institute, Karlsruhe.

Ragwitz, M.; Rathmann, M.; Winkel, T.; Stricker, E.; Held, A.; Pfluger, B.; Resch, G.; Panzer, C.; Busch, S. \& Konstantinaviciute, I. (2009), 'Renewable Energy Policy Country Profiles. 2009 Version', Technical report, ECOFYS, Fraunhofer ISI, Energy Economics Group, Lithuanian Energy Institute, Karlsruhe.

REN21 (2010), 'Renewables. Global status report. 2010 update', Technical report, Renewable Energy Policy Network for the 21st Century, Renewable Energy Policy Network for the 21st Century, Paris.

RES-Legal (2011), 'Legal Sources on Renewable Energy', German Federal Ministry for the Environment, Nature Conservation and Nuclear Safety, Berlin.

Schilling, M. A. \& Esmundo, M. (2009), 'Technology S-curves in renewable energy alternatives: Analysis and implications for industry and government', Energy Policy 37(5), 1767 - 1781.

Sensfuss, F. \& Ragwitz, M. (2007), 'Analyse des Preiseffektes der Stromerzeugung aus erneuerbaren Energien auf die Bursenpreise im deutschen Stromhandel', Technical report, Fraunhofer Institute for Systems and Innovation Research ISI, Fraunhofer Institute for Systems and Innovation Research ISI, Karlsruhe.

Shrimali, G. \& Kneifel, J. (2011), 'Are government policies effective in promoting deployment of renewable electricity resources?', Energy Policy 39(9), 4726 - 4741.

Simon, H. A. (1955), 'A behavioral model of rational choice', The Quarterly Journal of Economics 69(1), 99 - 118.

The World Bank (2011), 'Data', The World Bank Group, Washington, D.C.

U.S. Energy Information Administration (2011), 'The Electricity Access Database', U.S. Energy Information Administration, Washington, D.C.

United Nations Statistics Division (2011), 'UN Data. Energy Statistics Database', United Nations Organization, New York City, NY.

Weitzman, M. L. (1974), 'Prices vs. quantities', The Review of Economic Studies 41(4), 477 $-491$.

Wiser, R.; Namovicz, C.; Gielecki, M. \& Smith, R. (2007), 'Renewables Portfolio Standards: A Factual Introduction to Experience from the United States', .

Yin, H. \& Powers, N. (2009), 'Do state renewable portfolio standards promote in-state renewable generation?', Energy Policy 38(2), 1140 - 1149. 